\title{
Geochronology and geochemistry of the $c .80$ Ma Rutog granitic pluton, northwestern Tibet: implications for the tectonic evolution of the Lhasa Terrane
}

\author{
TAI-PING ZHAO*†, MEI-FU ZHOU \\ WEI CHEN* \\ *Guangzhou Institute of Geochemistry, Chinese Academy of Sciences, Guangzhou, P.R. China \\ $\ddagger$ Department of Earth Sciences, The University of Hong Kong, Hong Kong, P.R. China
}

(Received 28 May 2007; accepted 11 December 2007; First published online 11 June 2008)

\begin{abstract}
The Rutog granitic pluton lies in the Gangdese magmatic arc in the westernmost part of the Lhasa Terrane, NW Tibet, and has SHRIMP zircon U-Pb ages of $c$. $80 \mathrm{Ma}$. The pluton consists of granodiorite and monzogranite with $\mathrm{SiO}_{2}$ ranging from 62 to $72 \mathrm{wt} \%$ and $\mathrm{Al}_{2} \mathrm{O}_{3}$ from 15 to 17 wt \%. The rocks contain 2.33-4.93 wt $\% \mathrm{~K}_{2} \mathrm{O}$ and 3.42-5.52 wt $\% \mathrm{Na}_{2} \mathrm{O}$ and have $\mathrm{Na} 2 \mathrm{O} / \mathrm{K}_{2} \mathrm{O}$ ratios of $0.74-2.00$. Their chondrite-normalized rare earth element (REE) patterns are enriched in LREE ( $(\mathrm{La} / \mathrm{Yb}) \mathrm{n}=15$ to 26$)$ and do not show significant $\mathrm{Eu}$ anomalies $(\delta \mathrm{Eu}=0.68-1.15)$. On a primitive mantle-normalized trace element diagram, the rocks are rich in large ion lithophile elements (LILE) and poor in high field strength elements (HFSE), HREE and Y. Their Sr/Y ratios range from 15 to 78 with an average of 30 . The rocks have constant initial ${ }^{87} \mathrm{Sr} /{ }^{86} \mathrm{Sr}$ ratios $(0.7045$ to 0.7049$)$ and slightly positive $\varepsilon_{\mathrm{Nd}}(\mathrm{t})$ values $(+0.1$ to +2.3$)$, similar to I-type granites generated in an arc setting. The geochemistry of the Rutog pluton is best explained by partial melting of a thickened continental crust, triggered by underplating of basaltic magmas in a mantle wedge. The formation of the Rutog pluton suggests flat subduction of the Neo-Tethyan oceanic lithosphere from the south. Crustal thickening may have occurred in the Late Cretaceous prior to the India-Asia collision.
\end{abstract}

Keywords: Late Cretaceous, I-type granite, Rutog, Gangdese magmatic arc, Lhasa Terrane.

\section{Introduction}

Mesozoic and Cenozoic igneous rocks are widely distributed in the Lhasa Terrane, where they form the Gangdese magmatic arc (Coulon et al. 1986; TBGMR, 1993; Yin \& Harrison, 2000; Kapp et al. 2005). The arc is generally divided into the northern, central and southern belts (Pan, Wang \& Li, 2002; Pan et al. 2006; Lu, Zhang \& Ren, 2004). The southern and central belts have traditionally been interpreted as the result of northward low-angle subduction of Neo-Tethyan oceanic lithosphere beneath the Lhasa Terrane (Coulon et al. 1986; Hodges, 2000; Yin \& Harrison, 2000). In contrast, the northern belt has been considered to reflect subduction of Palaeo-Tethyan oceanic lithosphere, now represented by the BangongNujiang ophiolites, emplaced during collision between the Qiangtang and Lhasa terranes (Pan, Wang \& Li, 2002; Pan et al. 2006).

The Rutog pluton in the westernmost part of the Lhasa Terrane belongs to the northern belt of the Gangdese arc. Our new geochronological data reveal that the intrusion is a Late Mesozoic body. Thus, study of this body can provide important clues to the origin of the Mesozoic igneous rocks in the Gangdese arc and their role in the tectonic evolution of the Tibetan Plateau.

$\nmid$ †uthor for correspondence: tpzhao@gig.ac.cn
In this paper, we present new SHRIMP zircon dates, whole-rock major and trace element data and $\mathrm{Sr}-$ $\mathrm{Nd}$ isotopic analyses for the Rutog pluton. This new dataset documents that the pluton was formed by partial melting of thickened continental crust. The melting was probably triggered by underplated basaltic magmas produced during northward subduction of Neo-Tethyan oceanic lithosphere.

\section{Geological background}

Tibet is an amalgamation of terranes accreted to the southern margin of Eurasia during the Phanerozoic (Chang \& Zheng, 1973; Allègre et al. 1984). From north to south, it comprises the Qilian, KunlunQaidam, Songpan-Ganzi, Qiangtang and Lhasa terranes, which are separated from one another by major suture zones marked by ophiolitic fragments and mélanges (Yin \& Harrison, 2000). The Lhasa Terrane is separated from the Qiangtang Terrane to the north by the Bangong-Nujiang suture zone and from the Indian subcontinent to the south by the Yarlung-Zangbo suture zone (Fig. 1).

The Bangong-Nujiang suture zone, which extends for more than $1200 \mathrm{~km}$ across central Tibet, is marked by ophiolitic fragments and thick sequences of Jurassic flysch, mélange and volcanic rocks (Yin \& Harrison, 2000). The Jurassic ophiolitic fragments along this belt are unconformably overlain by upper Jurassic-upper 


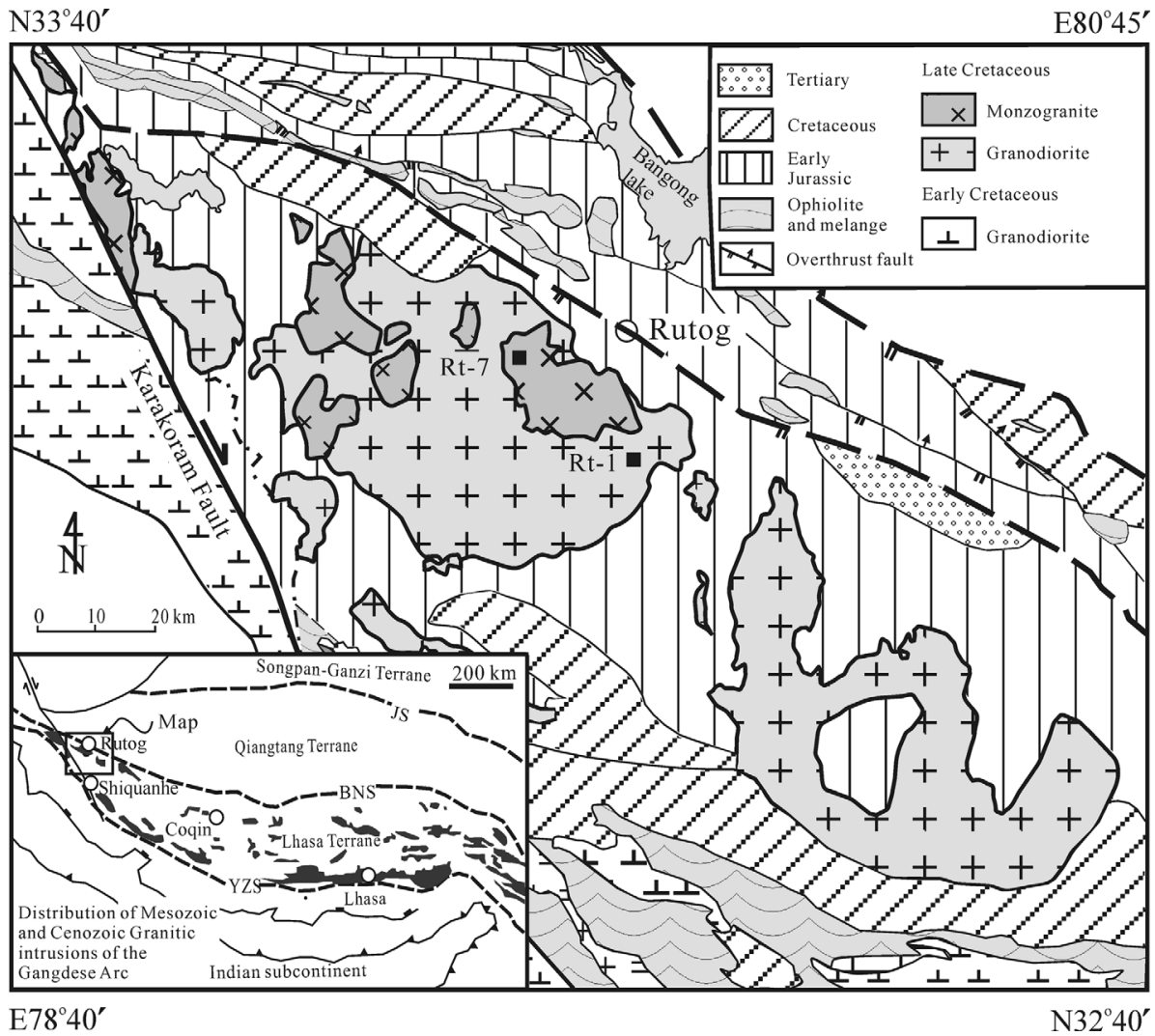

Figure 1. Simplified geological map of the Shiquanhe region, NW Tibet, showing the tectonic framework of the Tibetan Plateau (inset map) and the location of the Rutog pluton. JS - Jinshajiang suture; BNS - Bangong-Nujiang suture; YZS - Indus-Yarlung-Zangbo suture.

Cretaceous strata and were emplaced probably at $c$. $170 \mathrm{Ma}$ (Zhou et al. 1997; Yin \& Harrison, 2000). This ophiolitic belt is up to $100 \mathrm{~km}$ wide, probably reflecting the presence of intra-oceanic arc terranes (Pearce \& Mei, 1988; Matte et al. 1996).

The Yarlung-Zangbo suture zone contains several well-preserved fragments of Neo-Tethyan oceanic lithosphere that were emplaced in the Cretaceous (Allègre et al. 1984; Aitchison et al. 2000). Final continent-continent collision, leading to the present configuration, probably occurred in Eocene times (Molnar \& Tapponnier, 1975).

The Lhasa Terrane, 100 to $300 \mathrm{~km}$ wide, consists of a gneissic basement overlain by Palaeozoic to Cenozoic strata. Palaeozoic strata are represented by a sequence of Ordovician to Permian shallow marine sedimentary rocks (Yin \& Harrison, 2000). Lower Cretaceous sedimentary rocks are locally overlain by early Tertiary volcanic sequences of the Linzizong Formation (Allègre et al. 1984; Murphy et al. 1997).

The Linzizong Formation, together with Cretaceous-Early Tertiary granitic batholiths, comprise the Gangdese arc in the Lhasa Terrane (Allègre et al. 1984; Coulon et al. 1986; Kapp et al. 2005). The volcanic rocks consist chiefly of calcalkaline andesites and andesitic pyroclastic rocks, similar to those of the Andean continental-margin arc (Coulon et al. 1986; Mo et al. 2003).

Granitoids are widespread in the Shiquanhe area in the western part of the Lhasa Terrane (Fig. 1) and consist mainly of diorite and granodiorite. A muscovite-bearing granitic pluton intrudes Permian strata east of Shiquanhe. Synkinematic muscovite from a south-directed shear zone yielded a $\mathrm{K}-\mathrm{Ar}$ age of $83 \pm 4 \mathrm{Ma}$, which is believed to date reactivation of the suture zone near Bangong Lake (Ratschbacher et al. 1994). Ophiolitic mélange in Rutog has been thrust southward over lower Tertiary red beds, suggesting local shortening during the India-Asia collision (TBGMR, 1993).

\section{Petrography of the Rutog pluton}

The Rutog pluton is about $25-30 \mathrm{~km}$ wide and $190 \mathrm{~km}$ long, and crops out over an area of more than $3315 \mathrm{~km}^{2}$ (TBGMR, 1993) (Fig. 1). It intrudes Lower-Middle Jurassic and Lower Cretaceous strata, and the contact is marked locally by dark hornfels (TBGMR, 1993). The intrusion is compositionally zoned, with an early, marginal phase of granodiorite and a later phase of biotite monzogranite. Abundant dioritic xenoliths and small pegmatitic dykes occur throughout the intrusion.

The granodiorites are coarse-grained and porphyritic in the central part to fine-grained and aphyric along the margins. They are mainly composed of quartz $( \pm 20$ modal $\%)$, plagioclase $( \pm 50 \%)$, K-feldspar $(<10 \%)$ and biotite + hornblende $( \pm 15 \%)$. The plagioclase has well-developed oscillatory zoning, and some quartz grains contain needles of rutile. 
Table 1. SHRIMP zircon U-Pb analytical data for rocks from the Rutog pluton

\begin{tabular}{|c|c|c|c|c|c|c|c|c|c|c|c|c|c|}
\hline Spot & $\begin{array}{c}{ }^{206} \mathrm{~Pb}_{\mathrm{c}} \\
\%\end{array}$ & $\begin{array}{c}\mathrm{U} \\
\mathrm{ppm}\end{array}$ & $\begin{array}{c}\text { Th } \\
\text { ppm }\end{array}$ & $\begin{array}{c}{ }^{232} \mathrm{Th} / \\
{ }^{238} \mathrm{U}\end{array}$ & $\begin{array}{c}{ }^{206} \mathrm{~Pb}^{*} \\
\mathrm{ppm}\end{array}$ & $\begin{array}{c}{ }^{206} \mathrm{~Pb} /{ }^{238} \mathrm{U} \\
\text { age }\end{array}$ & $\begin{array}{c}{ }^{207} \mathrm{~Pb} /{ }^{206} \mathrm{~Pb} \\
\text { age }\end{array}$ & $\begin{array}{c}{ }^{207} \mathrm{~Pb}^{*} / \\
{ }^{206} \mathrm{~Pb}^{*}\end{array}$ & $\pm \%$ & $\begin{array}{c}{ }^{207} \mathrm{~Pb}^{*} / \\
{ }^{235} \mathrm{U}\end{array}$ & $\pm \%$ & $\begin{array}{c}{ }^{206} \mathrm{~Pb}^{*} / \\
{ }^{238} \mathrm{U}\end{array}$ & $\pm \%$ \\
\hline \multicolumn{14}{|c|}{ RT-1: granodiorite } \\
\hline RT1.1 & 2.39 & 75.4 & 40.7 & 0.558 & 0.869 & $84.0 \pm 2.2$ & $-481 \pm 590$ & 0.0381 & 22 & 0.0690 & 22 & 0.0131 & 2.7 \\
\hline RT1.2 & 0.48 & 390 & 120 & 0.319 & 4.20 & $79.9 \pm 1.7$ & $-47 \pm 91$ & 0.0452 & 3.1 & 0.0777 & 4.3 & 0.0125 & 2.2 \\
\hline RT1.3 & 2.38 & 42.7 & 36.7 & 0.889 & 0.506 & $86.4 \pm 2.4$ & $-606 \pm 450$ & 0.0363 & 17 & 0.0680 & 17 & 0.0135 & 2.8 \\
\hline RT1.4 & 0.95 & 128 & 117 & 0.947 & 1.49 & $86.2 \pm 2.0$ & $-81 \pm 210$ & 0.0445 & 8.6 & 0.0827 & 9.0 & 0.0135 & 2.4 \\
\hline RT1.5 & 1.39 & 157 & 60.3 & 0.398 & 1.86 & $87.2 \pm 2.0$ & $-333 \pm 240$ & 0.0403 & 9.4 & 0.0756 & 9.7 & 0.0136 & 2.3 \\
\hline RT1.6 & 1.61 & 107 & 65.8 & 0.636 & 1.25 & $85.6 \pm 2.1$ & $-276 \pm 310$ & 0.0412 & 12 & 0.0759 & 13 & 0.0134 & 2.4 \\
\hline RT1.7 & 6.45 & 25.9 & 16.5 & 0.660 & 0.285 & $77.1 \pm 2.9$ & $-770 \pm 1400$ & 0.0340 & 50 & 0.0570 & 50 & 0.0120 & 3.8 \\
\hline RT1.8 & 1.09 & 57.8 & 33.4 & 0.597 & 0.582 & $74.3 \pm 1.9$ & $82 \pm 270$ & 0.0477 & 11 & 0.0762 & 12 & 0.0116 & 2.6 \\
\hline RT1.9 & 3.17 & 22.7 & 15.2 & 0.691 & 0.255 & $80.9 \pm 2.8$ & $380 \pm 690$ & 0.0540 & 31 & 0.0940 & 31 & 0.0126 & 3.4 \\
\hline RT1.10 & 2.85 & 76.5 & 60.1 & 0.811 & 0.911 & $86.3 \pm 2.3$ & $-1108 \pm 830$ & 0.0305 & 27 & 0.0570 & 27 & 0.0135 & 2.6 \\
\hline RT1.11 & 4.10 & 28.2 & 18.9 & 0.695 & 0.324 & $82.3 \pm 2.8$ & $-740 \pm 1200$ & 0.0350 & 42 & 0.0610 & 4.2 & 0.0128 & 3.4 \\
\hline RT1.12 & 2.79 & 54.8 & 45.2 & 0.851 & 0.601 & $79.5 \pm 2.3$ & $-609 \pm 850$ & 0.0360 & 31 & 0.0620 & 31 & 0.0124 & 2.9 \\
\hline RT1.13 & 2.75 & 50.1 & 29.1 & 0.601 & 0.533 & $77.4 \pm 2.3$ & $-696 \pm 880$ & 0.0350 & 32 & 0.0590 & 32 & 0.0121 & 2.9 \\
\hline RT1.14 & 1.45 & 83.2 & 50.5 & 0.627 & 0.922 & $81.5 \pm 2.3$ & $-190 \pm 230$ & 0.0426 & 9.2 & 0.0747 & 9.6 & 0.0127 & 2.8 \\
\hline RT1.15 & 3.22 & 46.1 & 27.3 & 0.611 & 0.511 & $80.0 \pm 2.4$ & $-1080 \pm 1100$ & 0.0310 & 36 & 0.0530 & 36 & 0.0125 & 3.0 \\
\hline RT1.16 & 3.35 & 52.9 & 31.8 & 0.620 & 0.560 & $76.4 \pm 2.3$ & $-940 \pm 1000$ & 0.0320 & 36 & 0.0530 & 36 & 0.0119 & 3.0 \\
\hline RT1.17 & 2.66 & 49.1 & 36.6 & 0.771 & 0.518 & $76.7 \pm 2.4$ & $-656 \pm 580$ & 0.0357 & 21 & 0.0590 & 21 & .0 .0120 & 3.1 \\
\hline RT1.18 & 0.229 & 88.9 & 81.2 & 0.945 & 1.03 & $86.2 \pm 2.0$ & $249 \pm 120$ & 0.0512 & 5.2 & 0.0950 & 5.7 & 0.0135 & 2.4 \\
\hline RT1.19 & 1.84 & 61.0 & 29.5 & 0.499 & 0.679 & $81.5 \pm 2.1$ & $-458 \pm 460$ & 0.0384 & 17 & 0.0670 & 18 & 0.0127 & 2.6 \\
\hline \multicolumn{14}{|c|}{ Rt-7: monzogranite } \\
\hline RT7.1 & 0.298 & 138 & 115 & 0.859 & 1.37 & $73.9 \pm 1.7$ & $176 \pm 95$ & 0.0496 & 4.1 & 0.0788 & 4.7 & 0.0115 & 2.3 \\
\hline RT7.2 & 1.87 & 68.8 & 97.2 & 1.46 & 0.722 & $76.9 \pm 2.3$ & $117 \pm 350$ & 0.0484 & 15 & 0.0800 & 15 & 0.0120 & 2.9 \\
\hline RT7.3 & 0.781 & 121 & 85.7 & 0.730 & 1.30 & $79.2 \pm 1.8$ & $-187 \pm 190$ & 0.0427 & 7.7 & 0.0727 & 8.1 & 0.0124 & 2.3 \\
\hline RT7.4 & 0.587 & 177 & 125 & 0.726 & 1.78 & $74.6 \pm 1.7$ & $75 \pm 110$ & 0.0475 & 4.8 & 0.0762 & 5.3 & 0.0116 & 2.3 \\
\hline RT7.5 & 0.094 & 224 & 358 & 1.65 & 2.38 & $79.2 \pm 1.8$ & $155 \pm 61$ & 0.0491 & 2.6 & 0.0838 & 3.4 & 0.0124 & 2.2 \\
\hline RT7.6 & 0.337 & 253 & 351 & 1.44 & 2.70 & $79.4 \pm 1.7$ & $-37 \pm 120$ & 0.0453 & 5.0 & 0.0775 & 5.4 & 0.0124 & 2.2 \\
\hline RT7.7 & 1.51 & 51.0 & 39.0 & 0.790 & 0.546 & $78.7 \pm 2.0$ & $198 \pm 280$ & 0.0501 & 12 & 0.0850 & 12 & 0.0123 & 2.6 \\
\hline RT7.8 & 0.628 & 117 & 92.1 & 0.811 & 1.29 & $81.2 \pm 1.9$ & $-119 \pm 24$ & 0.0439 & 9.7 & 0.0767 & 10 & 0.0127 & 2.4 \\
\hline RT7.9 & 0.495 & 147 & 119 & 0.833 & 1.61 & $81.2 \pm 1.8$ & $-70 \pm 140$ & 0.0447 & 5.7 & 0.0782 & 6.1 & 0.0127 & 2.3 \\
\hline RT7.10 & 0.770 & 317 & 495 & 1.62 & 3.31 & $77.3 \pm 1.7$ & $61 \pm 100$ & 0.0472 & 4.3 & 0.0786 & 4.9 & 0.0121 & 2.2 \\
\hline RT7.11 & 0.694 & 184 & 195 & 1.10 & 1.98 & $80.1 \pm 1.8$ & $-130 \pm 140$ & 0.0436 & 5.7 & 0.0753 & 6.1 & 0.0125 & 2.3 \\
\hline RT7.12 & 1.14 & 96.7 & 80.7 & 0.862 & 1.11 & $84.5 \pm 2.0$ & $-144 \pm 180$ & 0.0434 & 7.2 & 0.0790 & 7.6 & 0.0132 & 2.4 \\
\hline RT7.13 & 0.425 & 102 & 91.2 & 0.923 & 1.15 & $83.6 \pm 2.0$ & $113 \pm 190$ & 0.0483 & 7.9 & 0.0868 & 8.2 & 0.0131 & 2.4 \\
\hline RT7.14 & 0.892 & 195 & 278 & 1.48 & 2.10 & $79.5 \pm 1.8$ & $-259 \pm 170$ & 0.0415 & 6.6 & 0.0710 & 7.0 & 0.0124 & 2.3 \\
\hline RT7.15 & 0.480 & 234 & 250 & 1.10 & 2.47 & $78.3 \pm 1.7$ & $-51 \pm 72$ & 0.0451 & 2.9 & 0.0760 & 3.7 & 0.0122 & 2.2 \\
\hline RT7.16 & 0.530 & 195 & 191 & 1.01 & 2.33 & $88.6 \pm 2.0$ & $30 \pm 110$ & 0.0466 & 4.7 & 0.0890 & 5.3 & 0.013 & 2.3 \\
\hline RT7.17 & 1.30 & 85.4 & 62.6 & 0.757 & 0.920 & $79.3 \pm 1.9$ & $25 \pm 180$ & 0.0465 & 7.4 & 0.0794 & 7.8 & 0.0124 & 2.4 \\
\hline RT7.18 & 0.583 & 102 & 70.5 & 0.715 & 1.10 & $79.9 \pm 1.9$ & $-34 \pm 160$ & 0.0454 & 6.5 & 0.0781 & 6.9 & 0.0125 & 2.4 \\
\hline RT7.1.1 & 0.355 & 355 & 724 & 2.11 & 3.25 & $68.1 \pm 1.5$ & $-68 \pm 55$ & 0.0448 & 2.2 & 0.0656 & 3.1 & 0.0106 & 2.2 \\
\hline
\end{tabular}

$\mathrm{Pb}_{\mathrm{C}}$ and $\mathrm{Pb}^{*}$ denote the common $\mathrm{Pb}$ and radiogenic $\mathrm{Pb}$, respectively, while the common $\mathrm{Pb}$ was corrected using non-radiogenic ${ }^{204} \mathrm{~Pb}$.

The biotite monzogranite crops out mainly in the northern part of the intrusion (Fig. 1) and is hosted in the granodiorite. The monzogranite is coarse-grained and porphyritic, and consists of quartz ( \pm 30 modal $\%)$, plagioclase $( \pm 30 \%)$, microcline perthite $( \pm 25 \%)$, biotite and hornblende $( \pm 10 \%)$. Accessory minerals include titanite, apatite, magnetite and zircon. The mineralogy suggests that these are I-type granites.

\section{Analytical methods}

\section{4.a. SHRIMP zircon dating}

Zircons were separated using magnetic and heavy liquid techniques, mounted in epoxy and ground to about half their thickness. Cathodoluminescence imaging was used to investigate the crystal zoning and to select analytical spots.

The zircon $\mathrm{U}-\mathrm{Pb}$ dating was performed at the SHRIMP Ion Probe Centre, Chinese Academy of Geological Sciences, Beijing. The analytical procedures are described in Zhao et al. (2004). The standard zircon, Temora (417 Ma), was used to correct for elemental fractionation, and standard SL13 was used to monitor analytical precision. Common $\mathrm{Pb}$ was corrected using non-radiogenic ${ }^{204} \mathrm{~Pb}$. The programs SQUID 1.02 and ISOPLOT were used to reduce the data (Ludwig, 2001), and IUGS values (Steiger \& Jäger, 1977) were used to calculate the ages. Uncertainties in Table 1 are reported at the $1 \sigma$ level and the mean ages are reported at the $95 \%$ confidence interval.

\section{4.b. Major and trace element analyses}

Samples from the Rutog pluton were analysed for major and trace elements at the Guangzhou Institute of Geochemistry, Chinese Academy of Sciences (Table 2). Samples were pulverized in a jaw crusher and then powdered in an agate mill to a grain size smaller than 160 mesh. Major oxides were determined using an X-ray fluorescence spectrometer (XRF) on glass discs, following the analytical procedures described by Goto \& Tatsumi (1996). Analytical uncertainties for most major elements are estimated to be less than $1 \%$, based on repeated analyses of U.S.G.S. standards BHVO-2 (basalt), MRG-1 (basalt) and W-2 (diabase). 
Table 2. Major and trace element compositions for Rutog granites

\begin{tabular}{|c|c|c|c|c|c|c|c|c|c|c|c|c|c|c|c|}
\hline Sample & RT-1 & RT-2-1 & RT-2-2 & RT-3-1 & RT-4-1 & RT-4-2 & RT-4-3 & RT-5-1 & RT-6-1 & RT-7 & RT-8 & RT-9-1 & RT-10-1 & RT-10-2 & RT-11 \\
\hline \multicolumn{16}{|c|}{ Major elements (wt\%) } \\
\hline $\mathrm{SiO}_{2}$ & 65.66 & 67.84 & 68.39 & 69.46 & 69.56 & 70.06 & 71.31 & 70.61 & 68.5 & 67.93 & 72.13 & 69.52 & 68.04 & 61.71 & 63.36 \\
\hline $\mathrm{TiO}_{2}$ & 0.75 & 0.47 & 0.51 & 0.44 & 0.23 & 0.45 & 0.37 & 0.48 & 0.51 & 0.51 & 0.39 & 0.50 & 0.56 & 0.88 & 0.91 \\
\hline $\mathrm{Al}_{2} \mathrm{O}_{3}$ & 16.26 & 16.09 & 15.65 & 15.81 & 16.82 & 14.86 & 14.52 & 14.61 & 14.91 & 16.28 & 14.67 & 15.03 & 15.37 & 17.04 & 15.37 \\
\hline $\mathrm{e}_{2} \mathrm{O}_{3}$ & 4.04 & 2.60 & 2.94 & 2.46 & 1.59 & 2.48 & 2.08 & 2.58 & 2.79 & 2.72 & 2.04 & 2.60 & 3.08 & 5.07 & 4.65 \\
\hline $\mathrm{MnO}$ & 0.06 & 0.04 & 0.05 & 0.04 & 0.03 & 0.04 & 0.04 & 0.05 & 0.04 & 0.05 & 0.04 & 0.05 & 0.05 & 0.10 & 0.07 \\
\hline $\mathrm{MgO}$ & 2.14 & 1.22 & 1.38 & 1.20 & 0.69 & 1.13 & 1.03 & 1.25 & 1.29 & 1.28 & 0.93 & 1.21 & 1.52 & 2.51 & 2.79 \\
\hline $\mathrm{CaO}$ & 4.09 & 2.74 & 3.08 & 2.53 & 2.76 & 1.78 & 2.13 & 2.64 & 1.97 & 3.16 & 0.59 & 2.76 & 2.94 & 3.97 & 5.00 \\
\hline $\mathrm{a}_{2} \mathrm{O}$ & 4.13 & 3.99 & 4.00 & 4.23 & 4.46 & 3.42 & 3.80 & 3.83 & 5.52 & 4.22 & 3.76 & 3.84 & 3.87 & 4.66 & 4.12 \\
\hline${ }_{2} \mathrm{O}$ & 2.44 & 4.17 & 3.41 & 3.64 & 3.83 & 4.63 & 4.12 & 3.58 & 2.97 & 3.60 & 4.93 & 3.66 & 4.01 & 2. & 3.51 \\
\hline${ }_{2} \mathrm{O}_{5}$ & 0.25 & 0.18 & 0.19 & 0.15 & 0.10 & 0.15 & 0.13 & 0.15 & 0.16 & 0.17 & 0.12 & 0.15 & 0.18 & 0.31 & 0.26 \\
\hline LOI & 0.58 & 0.65 & 0.65 & 0.62 & 0.48 & 1.09 & 0.31 & 0.39 & 1.67 & 0.47 & 0.99 & 0.50 & 0.55 & 1.54 & 0.54 \\
\hline Total & 100.40 & 99.99 & 100.24 & 100.57 & 100.54 & 100.09 & 99.86 & 100.17 & 100.33 & 100.38 & 100.59 & 99.81 & 100.17 & 100.09 & 100.59 \\
\hline ACNK & 0.96 & 1.00 & 0.99 & 1.02 & 1.02 & 1.07 & 1.00 & 0.98 & 0.94 & 0.98 & 1.17 & 0.98 & 0.96 & 0.98 & 0.78 \\
\hline \multicolumn{16}{|c|}{ Trace elements (ppm) } \\
\hline $\mathrm{Sc}$ & 7.16 & 3.70 & 4.30 & 3.09 & 1.44 & 3.41 & 2.10 & 3.65 & 3.58 & 4.03 & 1.42 & 3.04 & 4.15 & 13.5 & 7.46 \\
\hline V & 76.9 & 41.6 & 43.1 & 40.0 & 24.7 & 39.2 & 37.0 & 41.6 & 56.7 & 42.6 & 34.4 & 43.1 & 55. & & 81.0 \\
\hline $\mathrm{Cr}$ & 18.3 & 9.4 & 8.8 & 9.1 & 5.8 & 9.1 & 14.1 & 12.1 & 11.7 & nd & 6.5 & 12.7 & 16.3 & 33 & 53.9 \\
\hline $\mathrm{Ni}$ & 24.0 & 13.0 & 12.9 & 11.9 & 7.4 & 11.3 & 12.3 & 13.9 & 15.6 & 6.7 & 8.9 & 12.2 & 16.0 & 27 & 47.9 \\
\hline Co & 9.8 & 5.8 & 6.2 & 5.2 & 3.4 & 6.2 & 4.7 & 6.1 & 6.1 & 5.9 & 3.8 & 6.0 & 7.1 & 12.7 & 13.4 \\
\hline $\mathrm{Rb}$ & 72 & 154 & 134 & 136 & 153 & 138 & 163 & 137 & 112 & 157 & 202 & 164 & 151 & 137 & 149 \\
\hline & 463 & 332 & 305 & 28 & 408 & 299 & 249 & 2 & 289 & 355 & 18 & 30 & 31 & 35 & 441 \\
\hline $\mathrm{Zr}$ & 96 & 141 & 151 & 113 & 97 & 134 & 116 & 132 & 130 & 138 & 110 & 129 & 155 & 295 & 189 \\
\hline $\mathrm{Nb}$ & 11.9 & 12.2 & 12.4 & 12.1 & 6.7 & 12.5 & 10.5 & 14.6 & 11.9 & 13.4 & 15.2 & 15.3 & 15.8 & 26.1 & 20.8 \\
\hline $\mathrm{Ba}$ & 407 & 474 & 254 & 253 & 472 & 401 & 270 & 231 & 292 & 327 & 298 & 427 & 429 & 177 & 417 \\
\hline $\mathrm{Hf}$ & 2.63 & 3.77 & 4.15 & 3.12 & 2.85 & 3.84 & 3.10 & 3.58 & 3.39 & 3.62 & 3.03 & 3.79 & 4.18 & 7.37 & 4.97 \\
\hline $\mathrm{Ta}$ & & 1.10 & 1.07 & 1.16 & 0.63 & 1.18 & 0.84 & 1.28 & 0.98 & 1.35 & 1.32 & 1.53 & 1.41 & 2.48 & 1.65 \\
\hline $\mathrm{Pb}$ & 12.1 & 20.2 & 16.9 & 16.5 & 22.2 & 19.8 & 18.4 & 14.5 & 9.9 & 22.1 & 64.3 & 20.4 & 20.2 & 13.2 & 12.1 \\
\hline Th & 8.76 & 18.9 & 20.1 & 29.1 & 16.2 & 19.2 & 23.2 & 23.2 & 16.7 & 21.0 & 21.1 & 22.8 & 21. & 16. & 29.0 \\
\hline $\mathrm{U}$ & .34 & 2.96 & 4.49 & 3.81 & 2.83 & 4.46 & 3.91 & 2.86 & 1.94 & 2.94 & 2.64 & 2.98 & 4.28 & 4.39 & 4.51 \\
\hline $\mathrm{La}$ & 32.0 & 32.0 & 30.4 & 35.8 & 19.6 & 36.6 & 28.1 & 40.5 & 29.6 & 34.4 & 25.8 & 42.2 & 38.6 & 49.2 & 48.7 \\
\hline $\mathrm{Ce}$ & 59.3 & 55.9 & 52.8 & 56.4 & 30.0 & 61.7 & 47.5 & 70.2 & 53.2 & 66.2 & 45.5 & 74.5 & 71.0 & & 90.9 \\
\hline $\operatorname{Pr}$ & 70 & 6.15 & 86 & 5.99 & 2.93 & 6.92 & 4.92 & 7.30 & 5.68 & 6.85 & 5.07 & 7.90 & 7.65 & 11.78 & 9.99 \\
\hline $\mathrm{Nd}$ & 23.4 & 20.5 & 18.9 & 18.7 & 9.6 & 22.3 & 15.9 & 23.9 & 19.1 & 24.2 & 16.4 & 25.1 & 25.8 & 40.4 & 34.8 \\
\hline $\mathrm{Sm}$ & & & & & & & & 3.65 & & & & 3.93 & & & 5.68 \\
\hline $\mathrm{Eu}$ & & 0.81 & & 0.73 & & 0.7 & & 0.8 & & 0. & 0. & 0. & & 1.3 & 1.29 \\
\hline $\mathrm{Gd}$ & 3.25 & 2.51 & 2.36 & 2.09 & 1.23 & 2.53 & 1.80 & 2.73 & 2.36 & 3.29 & 1.96 & 2.93 & 3.26 & 4.79 & 4.60 \\
\hline $\mathrm{Tb}$ & & 0.38 & 0.35 & 0.30 & & 0.41 & & 0.42 & & 0.4 & & 0. & & 0.79 & 0.64 \\
\hline Dy & & 2.01 & 2.01 & 1.74 & & 2.28 & & 2.3 & 1.8 & 2.3 & 1. & 2. & 2.6 & 4.27 & 3.68 \\
\hline Но & 0.44 & 0.38 & 0.37 & 0.34 & 0.18 & 0.43 & 0.28 & 0.47 & 0.37 & 0.45 & 0.34 & 0.45 & 0.50 & 0.86 & 0.69 \\
\hline $\mathrm{Er}$ & & 1.04 & 1.03 & 0.95 & 0.5 & 1.19 & 0.7 & 1.29 & 1.0 & 1.2 & 0.93 & 1.3 & & 2.26 & 1.89 \\
\hline $\mathrm{Tm}$ & & 0.1 & 0. & 0.1 & & 0. & 0 . & 0.2 & 0 . & 0. & 0 . & 0.2 & 0.21 & 0.36 & 0.26 \\
\hline $\mathrm{Yb}$ & 1.12 & 1.09 & 1.07 & 0.98 & 0.60 & 1.24 & 0.8 & 1.28 & 0.99 & 1.2 & $1 .($ & 1.3 & 1.4 & 2.3 & 1.73 \\
\hline $\mathrm{Lu}$ & & & & 0.16 & & 0.19 & & 0.21 & 0.16 & 0.21 & 0.16 & 0.20 & 0.21 & 0.37 & 0.25 \\
\hline Y & 12.4 & 10.6 & 10.3 & 9.67 & 5.26 & 12.1 & 8.31 & 12.9 & 10.1 & 12.7 & 9.34 & 12.4 & 13.7 & 23.4 & 18.2 \\
\hline
\end{tabular}

LOI - Loss On Ignition; $\mathrm{ACNK}$ - molecular ratio of $\mathrm{Al}_{2} \mathrm{O}_{3} /\left(\mathrm{CaO}+\mathrm{Na}_{2} \mathrm{O}+\mathrm{K}_{2} \mathrm{O}\right)$.

The measured values of international standards are in satisfactory agreement with the recommended values.

Trace element data were obtained by Inductively Coupled Plasma-Mass Spectrometry (ICP-MS), following the analytical procedures described in $\mathrm{Qi}, \mathrm{Hu}$ \& Gregoire (2000). About $50 \mathrm{mg}$ of rock powder were dissolved in distilled $\mathrm{HF}-\mathrm{HNO}_{3}$ in Savillex screw-top Teflon ${ }^{\circledR}$ beakers held at $150{ }^{\circ} \mathrm{C}$ for four days. Analytical precision for REE and HFSE is estimated to be $5 \%$ from repeated analyses of U.S.G.S. standards, BHVO1 and $\mathrm{W}-2$.

\section{4.c. Sr and Nd isotope analyses}

For $\mathrm{Sr}-\mathrm{Nd}$ isotopic analyses, sample powders $(\sim 100 \mathrm{mg})$ were dissolved overnight in distilled $\mathrm{HF}-\mathrm{HNO}_{3}$ using Savillex screw-top Teflon ${ }^{\circledR}$ beakers at $150{ }^{\circ} \mathrm{C}$. Separation of $\mathrm{Nd}$ from the REE was carried out on HDEHP columns with a $0.18 \mathrm{~N} \mathrm{HCl}$ elutant. The isotopic analyses were performed using a Micromass Isoprobe Multi-Collector ICP-MS, also at the Guangzhou Institute of Geochemistry.

Measured $\mathrm{Sr}$ and $\mathrm{Nd}$ isotopic ratios were normalized using a ${ }^{86} \mathrm{Sr} /{ }^{88} \mathrm{Sr}$ value of 0.1194 and a ${ }^{146} \mathrm{Nd} /{ }^{144} \mathrm{Nd}$ value of 0.7219 . The $\mathrm{Sr}$ and $\mathrm{Nd}$ blanks were 0.5 and $0.3 \mathrm{ng}$, respectively. Analyses of standards gave the following results: NBS987 ${ }^{87} \mathrm{Sr} /{ }^{86} \mathrm{Sr}=0.710243 \pm 14$ $(2 \sigma)$ and Shin Etou ${ }^{143} \mathrm{Nd} /{ }^{144} \mathrm{Nd}=0.512124 \pm 11(2 \sigma)$, equivalent to a value of 0.511860 for the La Jolla international standard (Tanaka et al. 2004).

\section{Analytical results}

\section{5.a. SHRIMP zircon dating results}

Zircons used for SHRIMP U-Pb dating were separated from a granodiorite (RT-1) and a monzogranite (RT7). Zircons from the granodiorite (RT-1) are euhedral and prismatic with clear oscillatory zoning indicating 

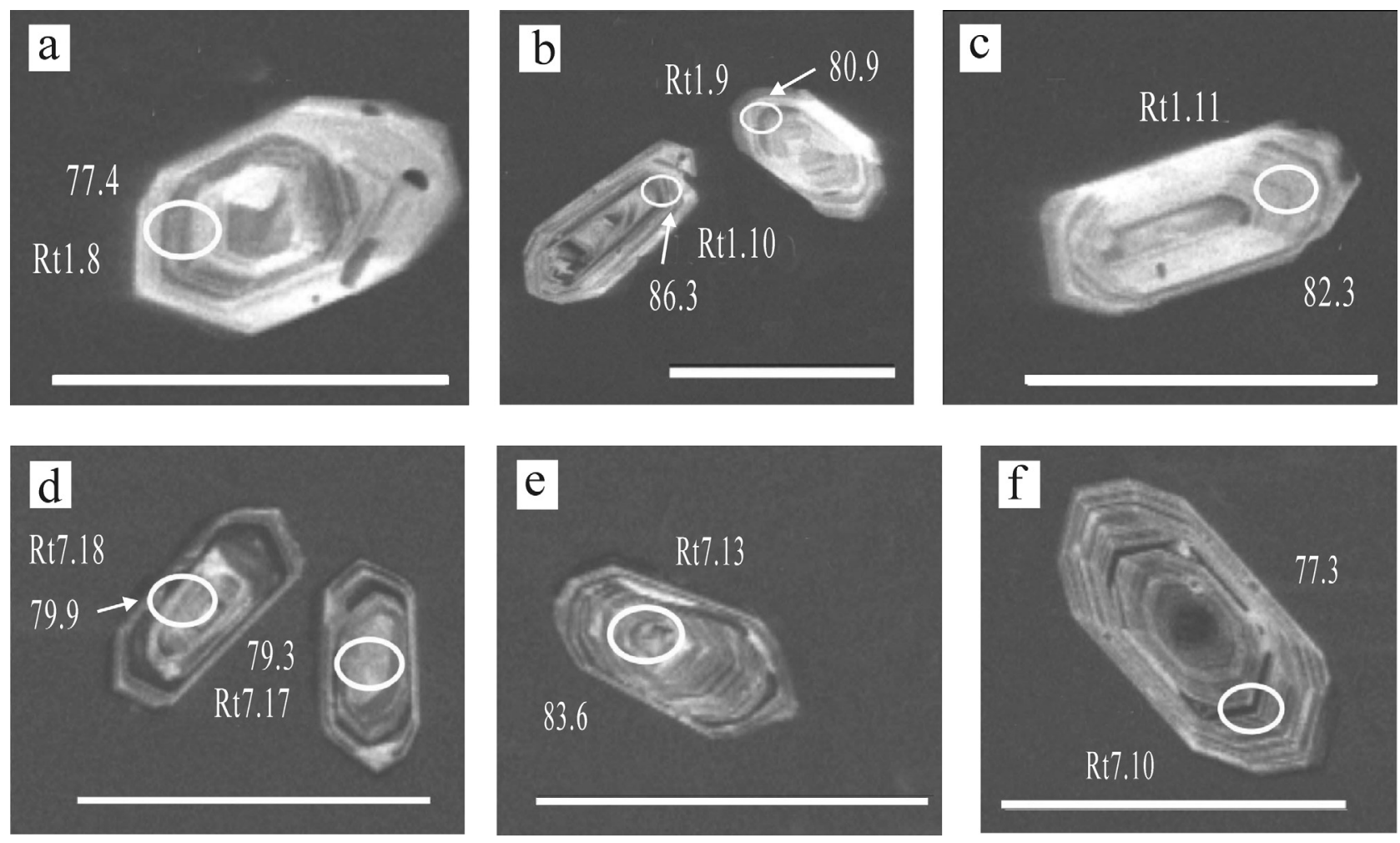

Figure 2. Cathodoluminescence images of zircons from the Rutog pluton. SHRIMP analysis points are white circles. The scale is $200 \mu \mathrm{m}$.

a magmatic origin (Fig. 2). These zircons have length to width ratios of $2: 1$ to $3: 1$.

Cathodoluminescence (CL) imaging reveals that there are some mineral inclusions (e.g. spots RT-1.5 and RT-1.6). A total of 20 analyses were obtained, with Th contents ranging from 15 to $120 \mathrm{ppm}$ and $\mathrm{U}$ from 23 to $390 \mathrm{ppm}$, giving $\mathrm{Th} / \mathrm{U}$ ratios of 0.32 to 0.95 . The analytical results are listed in Table 1 and shown on concordia plots in Figure 3. Fourteen analyses from the inner and outer parts of different grains form a tight cluster with an average ${ }^{206} \mathrm{~Pb}$ ${ }^{238} \mathrm{U}$ age of $80.0 \pm 1.2 \mathrm{Ma}$. Six analyses yield slightly younger ${ }^{206} \mathrm{~Pb}-{ }^{238} \mathrm{U}$ ages due to high $\mathrm{U}$ contents or loss of $\mathrm{Pb}$.

Zircons from the monzogranite (RT-7) contain many inclusions and have well-defined magmatic zoning revealed by CL imaging (Fig. 2). Only those zircons without inclusions or inherited cores were selected for analysis. Nineteen analyses have Th contents ranging from 39 to $195 \mathrm{ppm}$ and $\mathrm{U}$ contents from 51 to $317 \mathrm{ppm}$, yielding $\mathrm{Th} / \mathrm{U}$ ratios of 0.71 to 1.61 (Table 1). Sixteen of the analyses plot near the concordia and yield ${ }^{206} \mathrm{~Pb}-{ }^{238} \mathrm{U}$ ages ranging from $74.6 \pm 1.7 \mathrm{Ma}$ to $84.5 \pm 0.2 \mathrm{Ma}$ with a weighted average of $79.4 \pm 0.9 \mathrm{Ma}$ (Fig. 3). Two points have large errors in the ${ }^{206} \mathrm{~Pb}-{ }^{238} \mathrm{U}$ ages, although they are still within the analytical uncertainties. One analysis (RT-7.1.1) has $355 \mathrm{ppm}$ U, $724 \mathrm{ppm}$ Th and $3.25 \mathrm{ppm}$ $\mathrm{Pb}$ and yielded an age of $68.1 \pm 1.5 \mathrm{Ma}$. The ratios of $\mathrm{Pb} / \mathrm{U}$ and $\mathrm{Pb} / \mathrm{Th}$ are 0.009 and 0.004 , respectively, which are the lowest among all the zircons. This analysis is not included in the final calculation.
The granodiorite and monzogranite have identical ${ }^{206} \mathrm{~Pb}{ }^{238} \mathrm{U}$ ages of $80.0 \pm 1.2 \mathrm{Ma}$ and $79.4 \pm 0.9 \mathrm{Ma}$, respectively, suggesting that the Rutog pluton formed in the late Cretaceous (c. $80 \mathrm{Ma}$ ).

\section{5.b. Major and trace elements}

Both the granodiorites and monzogranites have similar compositions, with $\mathrm{SiO}_{2}$ ranging from 61.7 to $72.1 \mathrm{wt} \%, \mathrm{Al}_{2} \mathrm{O}_{3}$ from 14.5 to $17.0 \mathrm{wt} \%, \mathrm{Fe}_{2} \mathrm{O}_{3}$ from 1.59 to $5.07 \mathrm{wt} \%$ and $\mathrm{MgO}$ from 0.69 to $2.79 \mathrm{wt} \%$ (Table 2). Their $\mathrm{K}_{2} \mathrm{O}$ ranges from 2.33 to $4.93 \mathrm{wt} \%$ and $\mathrm{Na}_{2} \mathrm{O}$ from 3.42 to $5.52 \mathrm{wt} \%$, yielding $\mathrm{Na}_{2} \mathrm{O} / \mathrm{K}_{2} \mathrm{O}$ ratios of 0.7 to 2.0 (average of 1.2). They have $\mathrm{Mg}$ no. ranging from 12.0 to 15.9 , with an average of 13.2. Most samples have $\mathrm{A} / \mathrm{CNK}$ (molecular ratio of $\mathrm{Al}_{2} \mathrm{O}_{3} / \mathrm{CaO}$ $+\mathrm{Na}_{2} \mathrm{O}+\mathrm{K}_{2} \mathrm{O}$ )) values less than 1.1, indicating that they are Al-undersaturated. There are obvious negative correlations between $\mathrm{SiO}_{2}$ and $\mathrm{Fe}_{2} \mathrm{O}_{3}, \mathrm{TiO}_{2}, \mathrm{MgO}$ and $\mathrm{CaO}$, and positive correlations between $\mathrm{SiO}_{2}$ and $\mathrm{K}_{2} \mathrm{O}$ (Fig. 4). These relationships suggest fractionation of ilmenite and plagioclase.

The rocks have high La (19.6 to $49.2 \mathrm{ppm}$ ) and low $\mathrm{Yb}(0.6$ to $2.3 \mathrm{ppm})$, yielding high $(\mathrm{La} / \mathrm{Yb}) \mathrm{n}$ ratios of 15-26. They have LREE-enriched chondritenormalized REE patterns with slightly negative $\mathrm{Eu}$ anomalies $(\delta \mathrm{Eu}=0.68-1.15)$ (Fig. 5). All samples are also enriched in LILE and depleted in HFSE, and display negative $\mathrm{Nb}-\mathrm{Ta}$ and positive $\mathrm{Zr}-\mathrm{Hf}$ anomalies in the primitive mantle-normalized trace element diagram (Fig. 6). They have relatively high $\mathrm{Sr}(163$ to $185 \mathrm{ppm}$ ) and high $\mathrm{Sr} / \mathrm{Y}$ ratios (15 to 78 , average 30) (Table 2). 

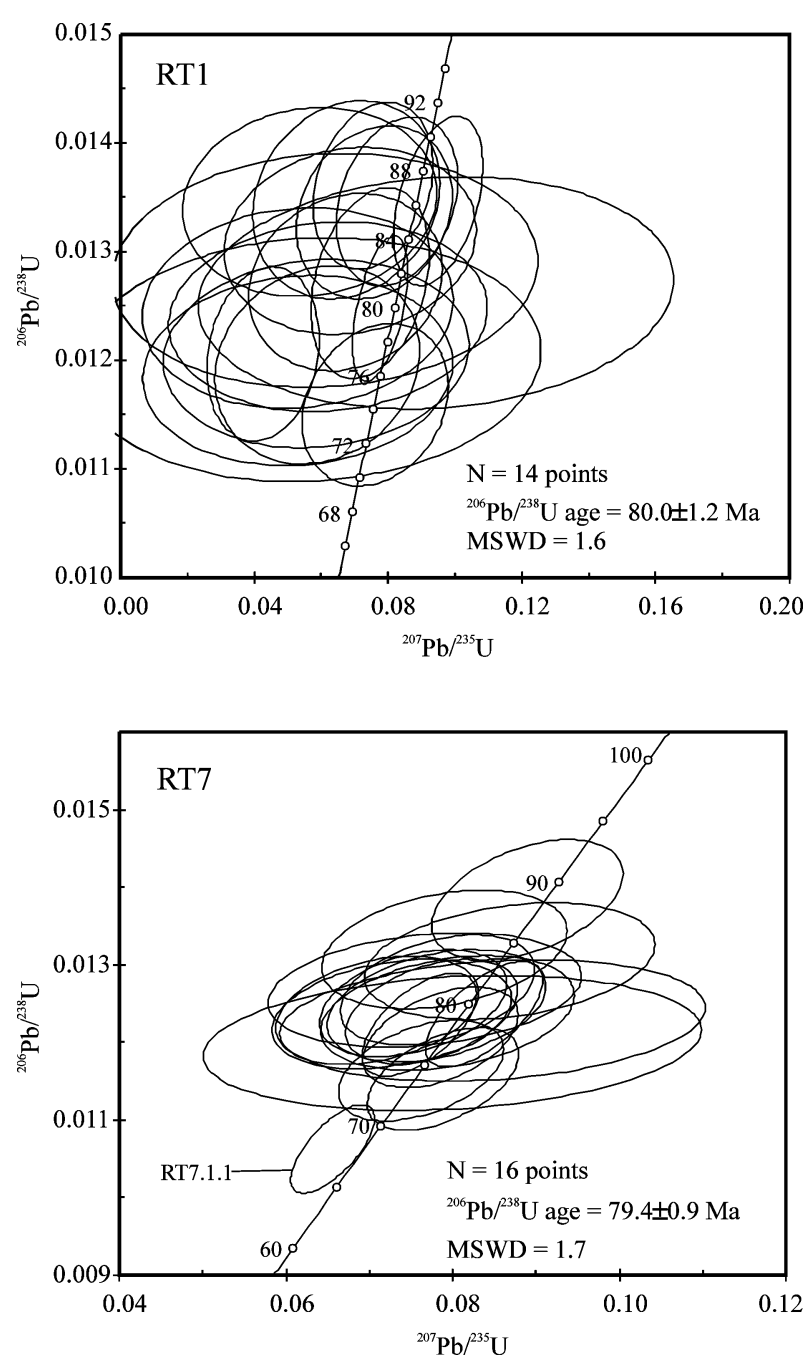

Figure 3. SHRIMP U-Pb concordia plots of zircons from the Rutog pluton.

\section{5.c. $\mathrm{Rb}-\mathrm{Sr}$ and $\mathrm{Sm}-\mathrm{Nd}$ isotopes}

Samples from the Rutog pluton have a wide range of ${ }^{87} \mathrm{Rb} /{ }^{86} \mathrm{Sr}$ ratios (0.45 to 3.15$)$, but a narrow range of initial ${ }^{87} \mathrm{Sr} /{ }^{86} \mathrm{Sr}$ ratios (0.7045 to 0.7049$)$ (Table 3). Their $f_{\mathrm{Sm} / \mathrm{Nd}}$ values range from -0.48 to -0.53 , within the range of $-0.4 \pm 0.2$ for corrected $\mathrm{T}_{\mathrm{DM}}$ calculation (Wu et al. 2003a). Therefore, we use a single model age for the discussion. Their initial ${ }^{143} \mathrm{Nd} /{ }^{144} \mathrm{Nd}$ ratios range from 0.5125 to 0.5126 and $\varepsilon_{\mathrm{Nd}}(\mathrm{t}=80 \mathrm{Ma})$ values range from +0.1 to +2.3 with $\mathrm{Nd}$ model ages $\left(\mathrm{T}_{\mathrm{DM}}\right)$ of $0.59-0.75 \mathrm{Ga}$. All samples have higher initial ${ }^{87} \mathrm{Sr} /{ }^{86} \mathrm{Sr}$ ratios than the mantle array in the plot of $\mathrm{Sr}$ versus $\mathrm{Nd}$ isotopes (Fig. 7).

\section{Discussion}

\section{6.a. Classification of the Rutog granitic rocks}

According to their protolith, granitic rocks are normally classified into I-, S-, M- and A-types (Chappell \& White, 1974; Pitcher, 1982, 1993).

Chappell \& White $(1992,2001)$ pointed out that Itype granites commonly display more regular linear variations in their chemical compositions than S-type granites, which generally display poor correlations between $\mathrm{SiO}_{2}$ and $\mathrm{P}_{2} \mathrm{O}_{5}$ and between $\mathrm{SiO}_{2}$ and $\mathrm{Pb}$, different from I-type granitoids (Chappell \& White, 1992). Well-defined linear trends in the Harker diagrams and a negative correlation between $\mathrm{SiO}_{2}$ and $\mathrm{P}_{2} \mathrm{O}_{5}$ suggest that the Rutog rocks are unlikely to be S-type granitoids (Fig. 4).

I-type granitic rocks normally have high $\mathrm{Na}_{2} \mathrm{O}$, $\mathrm{CaO}$ and low $\mathrm{Al}_{2} \mathrm{O}_{3}$ and $\mathrm{A} / \mathrm{CNK}$ values (molar $\left.\mathrm{Al}_{2} \mathrm{O}_{3} /\left(\mathrm{CaO}+\mathrm{Na}_{2} \mathrm{O}+\mathrm{K}_{2} \mathrm{O}\right)<1.1\right)$ compared to S-type granitoids, although there may be some overlap between them as observed in the Lachlan Fold Belt (Chappell \& White, 2001). The relatively high $\mathrm{Na}_{2} \mathrm{O}$ (3.42-5.52 wt \%) and $\mathrm{K}_{2} \mathrm{O}(2.33-4.93 \mathrm{wt} \%)$ and low $\mathrm{Al}_{2} \mathrm{O}_{3}$ (14.52 to $\left.17.04 \mathrm{wt} \%\right)$ and aluminum saturation index $\mathrm{A} / \mathrm{CNK}$ values (0.78 to 1.17 ) of the Rutog granitoids are consistent with an I-type classification. This classification is also supported by their low normative corundum ( $<1.0$ vol. \%, except sample RT-8).

The Rutog granitoids do not contain mafic alkaline minerals such as arfvedsonite and riebeckite, and they have low concentrations of $\mathrm{Na}_{2} \mathrm{O}+\mathrm{K}_{2} \mathrm{O}(6.57$ to $8.69 \mathrm{wt} \%)$, low $\left(\mathrm{Na}_{2} \mathrm{O}+\mathrm{K}_{2} \mathrm{O}\right) / \mathrm{CaO}(1.53-14.7)$, $\mathrm{Fe}_{2} \mathrm{O}_{3} / \mathrm{MgO}(1.67-2.30)$ and $1000 \mathrm{Ga} / \mathrm{Al}(1.82-2.39)$ ratios compared to A-type granitoids (Whalen, Currie \& Chappell, 1987). They are also depleted in $\mathrm{Nb}, \mathrm{Zr}$, $\mathrm{Ce}$ and $\mathrm{Y}$, again typical of I-type granitoids (Whalen, Currie \& Chappell, 1987).

\section{6.b. Magmatic differentiation}

Fractional crystallization normally occurs during magma emplacement. The negative correlation between $\mathrm{SiO}_{2}$ and $\mathrm{MgO}$ of the Rutog granitoids (Fig. 4) suggests accumulation/fractionation of mafic minerals

Table 3. Sr-Nd isotope compositions of rocks from the Rutog pluton

\begin{tabular}{|c|c|c|c|c|c|c|c|c|c|c|c|c|c|}
\hline Sample & $\begin{array}{c}\mathrm{Rb} \\
\mathrm{ppm}\end{array}$ & $\begin{array}{c}\mathrm{Sr} \\
\text { ppm }\end{array}$ & ${ }^{87} \mathrm{Sr} /{ }^{86} \mathrm{Sr}$ & ${ }^{87} \mathrm{Rb} /{ }^{86} \mathrm{Sr}$ & $\left({ }^{87} \mathrm{Sr} /{ }^{86} \mathrm{Sr}\right) \mathrm{i}$ & Esr & $\begin{array}{c}\mathrm{Nd} \\
\mathrm{ppm}\end{array}$ & $\begin{array}{l}\text { Sm } \\
\text { ppm }\end{array}$ & ${ }^{143} \mathrm{Nd} /{ }^{144} \mathrm{Nd}$ & ${ }^{147} \mathrm{Sm} /{ }^{144} \mathrm{Nd}$ & $\left({ }^{143} \mathrm{Nd}^{/ 144} \mathrm{Nd}\right) \mathrm{i}$ & $\mathrm{T}_{\mathrm{DM}}(\mathrm{Ga})$ & $\varepsilon_{\mathrm{Nd}}$ \\
\hline RT-1 & 71.0 & 463 & 0.7055 & 0.4499 & 0.7049 & 7.7 & 23.4 & 3.99 & 0.512602 & 0.1029 & 0.512548 & 0.75 & 0.2 \\
\hline RT-2-1 & 154 & 332 & 0.7064 & 1.3436 & 0.7049 & 7.3 & 20.5 & 3.28 & 0.512593 & 0.0970 & 0.512542 & 0.73 & 0.1 \\
\hline RT-4-3 & 163 & 249 & 0.7070 & 1.8945 & 0.7048 & 5.7 & 15.9 & 2.60 & 0.512606 & 0.0990 & 0.512555 & 0.72 & 0.4 \\
\hline RT-5-1 & 137 & 283 & 0.7063 & 1.3971 & 0.7047 & 3.7 & 23.9 & 3.65 & 0.512600 & 0.0924 & 0.512551 & 0.69 & 0.3 \\
\hline RT-7 & 157 & 3559 & 0.7061 & 1.2833 & 0.7047 & 3.6 & 24.2 & 3.72 & 0.512650 & 0.0931 & 0.512601 & 0.63 & 1.3 \\
\hline RT-8 & 202 & 185 & 0.7085 & 3.1499 & 0.7049 & 6.7 & 16.4 & 2.69 & 0.512646 & 0.0991 & 0.512594 & 0.67 & 1.2 \\
\hline RT-10-1 & 151 & 313 & 0.7065 & 1.3991 & 0.7049 & 7.5 & 25.8 & 4.18 & 0.512627 & 0.0981 & 0.512576 & 0.69 & 0.8 \\
\hline RT-11 & 149 & 441 & 0.7057 & 0.9781 & 0.7046 & 2.5 & 34.8 & 5.68 & 0.512704 & 0.0988 & 0.512652 & 0.59 & 2.3 \\
\hline
\end{tabular}



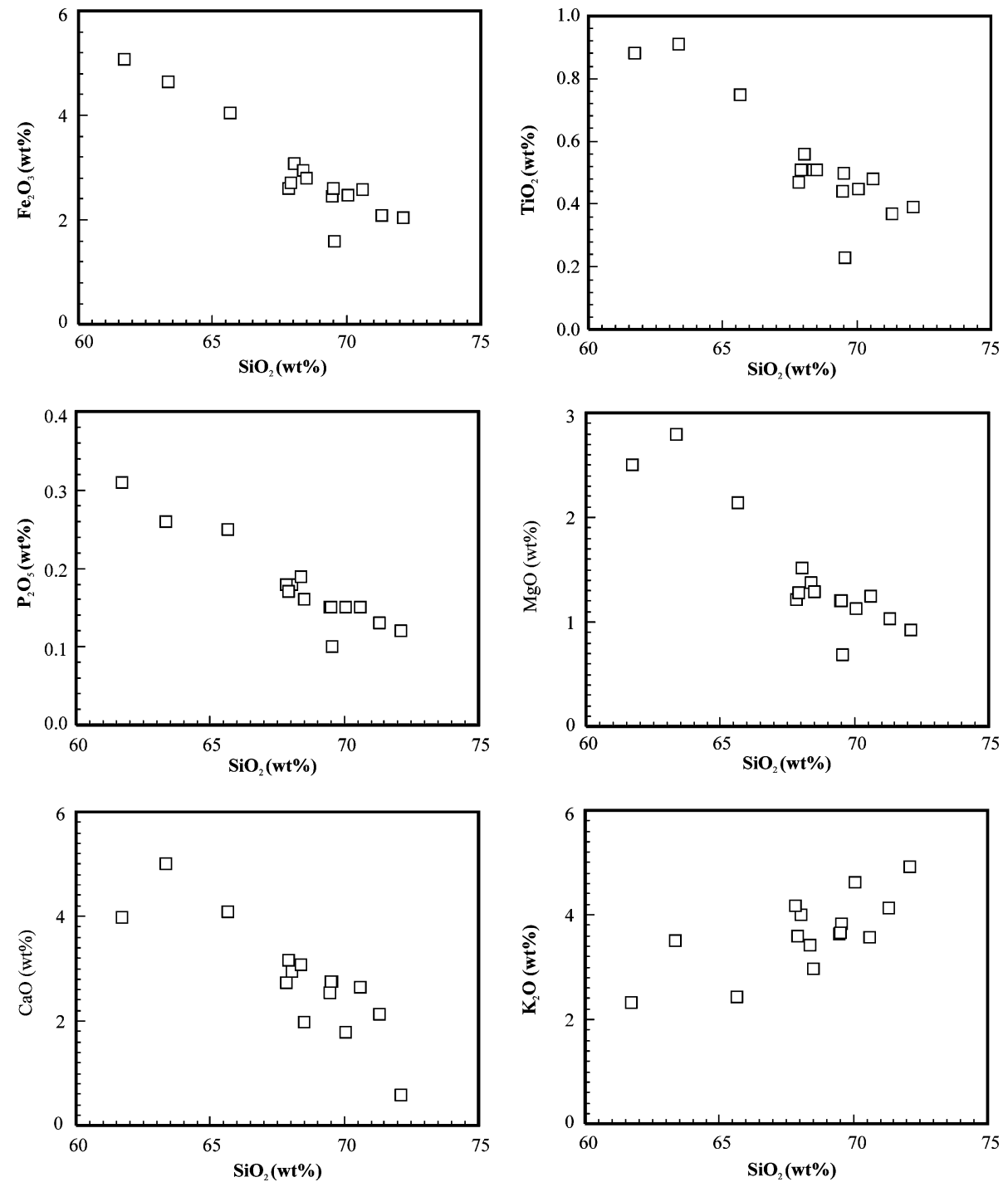

Figure 4. $\mathrm{SiO}_{2}$ v. other major element oxides of rocks of the Rutog pluton.

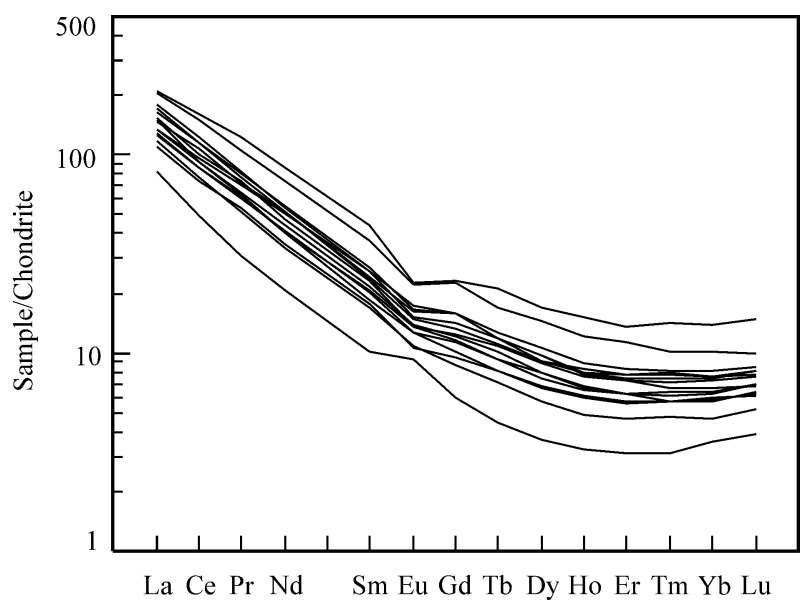

Figure 5. Chondrite-normalized REE patterns for rocks from the Rutog pluton. Normalization values are from Sun \& McDonough (1989).

such as hornblende and biotite. Obvious $\mathrm{Eu}, \mathrm{Sr}$ and Ba negative anomalies (Figs 5, 6) further demonstrate the fractionation of plagioclase (Wu et al. 2003b). A

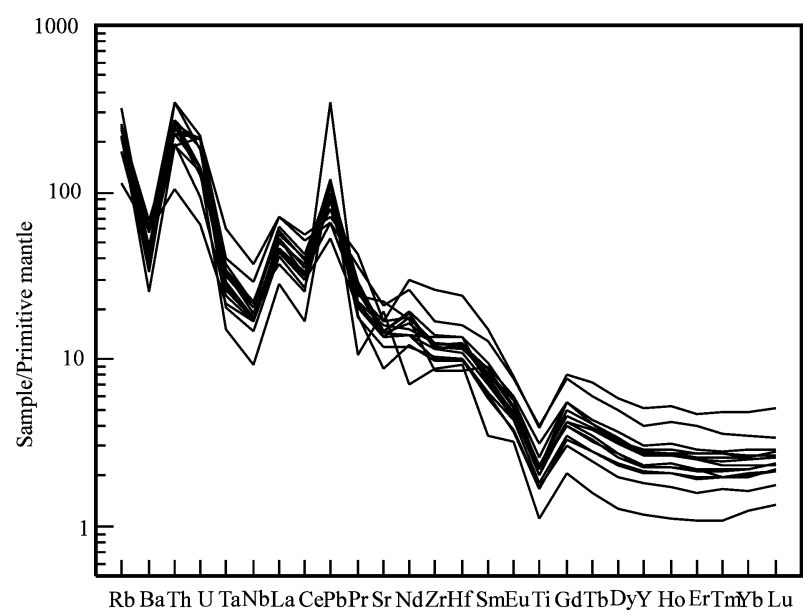

Figure 6. Primitive mantle-normalized trace-element diagram for rocks from the Rutog pluton. Normalization values are from Sun \& McDonough (1989).

positive correlation between $\mathrm{Sr}$ and $\mathrm{Ba}$ (Fig. 8a) further indicates the fractionation of plagioclase $(\mathrm{Li}$ et al. 2007). There is only a weak correlation between $\mathrm{Rb}$ 


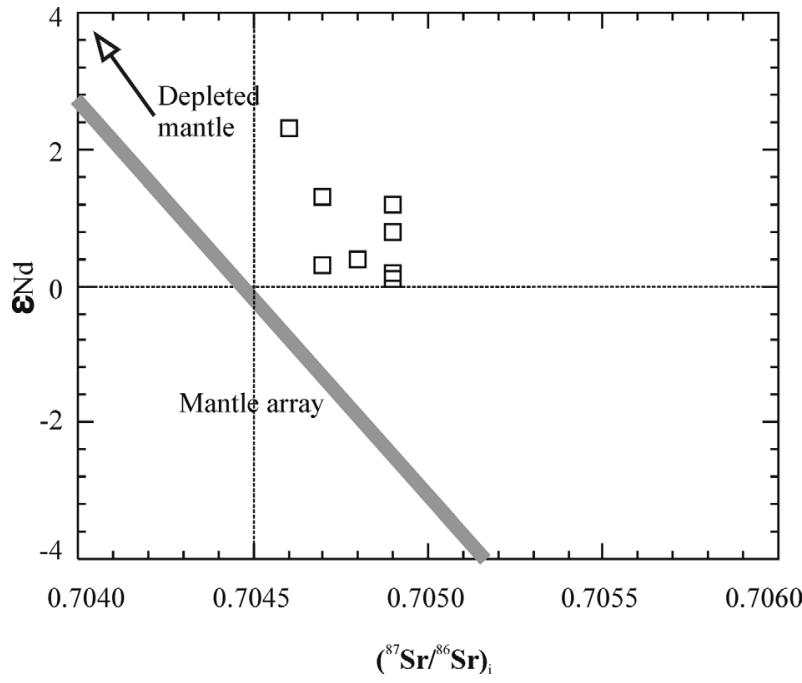

Figure 7. Plots of $\mathrm{Sr}-\mathrm{Nd}$ isotopes for rocks from the Rutog pluton.

and $\mathrm{Sr}$ (Fig. 8b), suggesting that K-feldspar was not a fractionating mineral.

Separation of Ti-bearing minerals (such as ilmenite and titanite) and apatite lead to depletion of $\mathrm{Nb}-\mathrm{Ta}-\mathrm{Ti}$
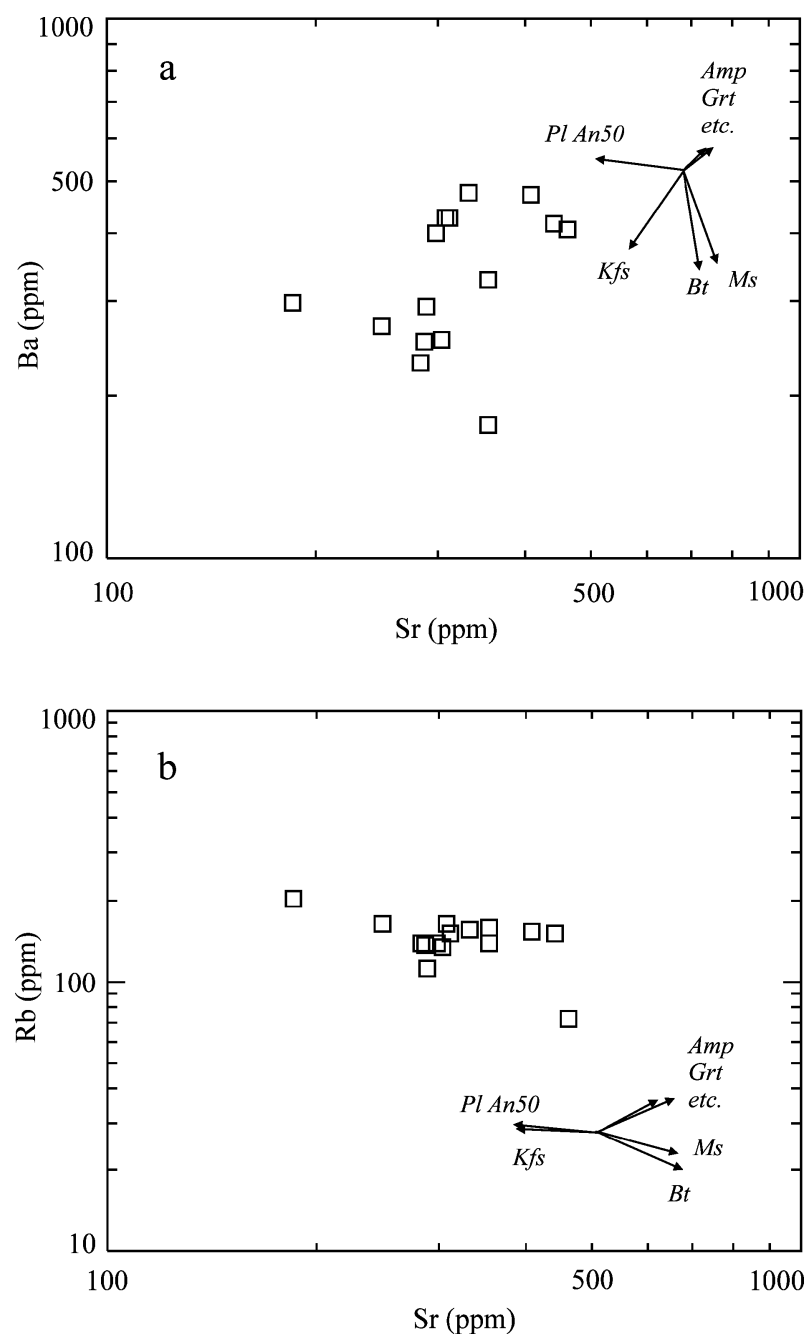

Figure 8. Fractional crystallization vector diagrams of $\mathrm{Sr} \mathrm{v}$. Ba (a) and $\mathrm{Sr} \mathrm{v} . \mathrm{Rb}$ (b) for the Rutog granites. The vectors are from Li et al. (2007).

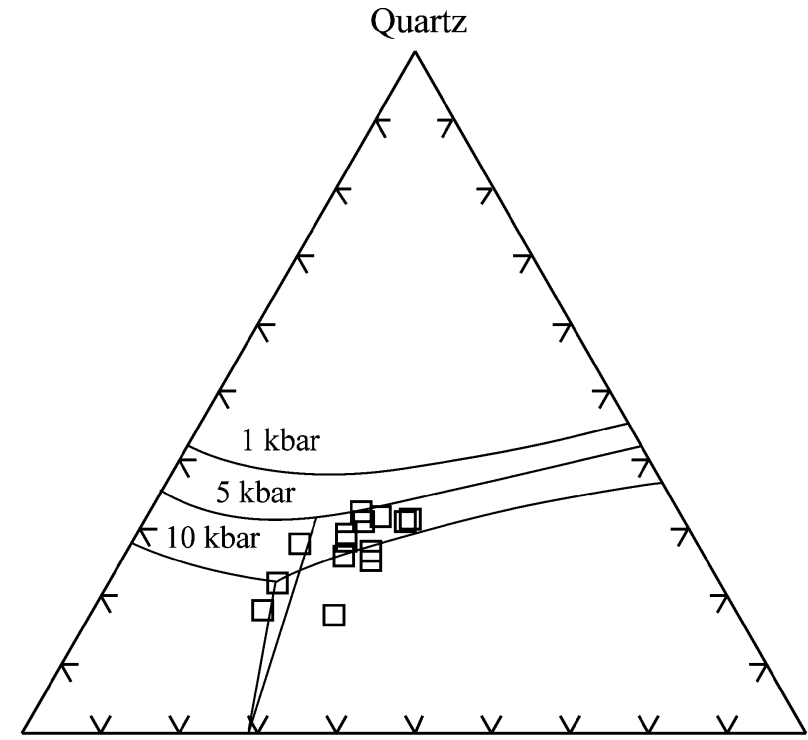

Albite

Orthoclase

Figure 9. CIPW-normative Qz-Ab-Or diagram with lowtemperature melt compositions at 1,5 and 10 kbar (Johannes \& Holtz, 1996).

and $\mathrm{P}$, respectively (Wu et al. 2003b). The strong depletion of $\mathrm{Nb}-\mathrm{Ta}-\mathrm{Ti}$ of the Rutog rocks (Fig. 6) indicates fractionation of Ti-bearing phases, and the negative correlation of $\mathrm{P}_{2} \mathrm{O}_{5}$ with $\mathrm{SiO}_{2}$ is consistent with fractionation of apatite.

In the CIPW-normative $\mathrm{Qz}-\mathrm{Ab}-\mathrm{Or}$ diagram (Fig. 9), most samples plot in the low-pressure field between $10 \mathrm{kbar}$ and $5 \mathrm{kbar}$, and to the right of the cotectic/eutectic minima of the $\mathrm{H}_{2} \mathrm{O}$-saturated haplogranite system, typical of high-level emplacement of natural low-temperature granites (Johannes \& Holtz, 1996), suggesting that the Rutog granodiorites were emplaced at pressures less than 1.2 GPa. This conclusion is also consistent with unidirectional growth of dendritic alkali feldspar (Shannon et al. 1982).

\section{6.c. Petrogenesis of the Rutog pluton}

It is well known that I-type granites can be produced by (1) mafic mineral fractionation at an early stage of mantle-derived magmas, (2) mixing between mantle and crustal melts and (3) partial melting of mafic crust.

Fractional crystallization during the early stages of mafic magma evolution may produce evolved felsic magmas (e.g. Litvinovsky et al. 2002). Although the Rutog granitoids experienced low-pressure fractional crystallization of amphibole and feldspars as discussed above, there is little evidence that the Rutog rocks were produced by differentiation of mantle-derived melts. Granitoids produced by differentiation of such melts should have model ages approximately similar to their emplacement age (e.g. Sun \& Zhou, 2008). However, the Rutog granitoids have one-stage SmNd modal ages $(0.59-0.75 \mathrm{Ga})$ that are much older than their SHRIMP zircon $\mathrm{U}-\mathrm{Pb}$ ages of $c .80 \mathrm{Ma}$. In 
addition, no mafic plutons have been identified in the region. Therefore, it is highly unlikely that the Rutog pluton was a product of differentiation from mafic magmas.

Mixing between mantle-derived mafic magma and crustal felsic melts can also produce I-type granites (Chappell, 1996; Yang et al. 2007). However, the Rutog granitoids have relatively homogeneous compositions, which are atypical of rocks formed by magma mixing. Rocks formed by magma mixing may have different types of zircon with distinct morphologies (Yang et al. 2007). Zircons from the Rutog pluton are all euhedral and prismatic with clear oscillatory zoning (Fig. 2), and two samples produce identical U-Pb ages (Fig. 3), suggesting that they were yielded from a homogeneous source region, rather than from mixing of mafic and felsic magmas. In addition, the Rutog rocks have relatively constant ${ }^{87} \mathrm{Sr} /{ }^{86} \mathrm{Sr}$ ratios $(0.7045-$ $0.7049)$, high $\varepsilon \mathrm{Nd}(\mathrm{t})$ values $(+0.1$ to +2.3$)$, and uniform REE and trace elemental patterns, all of which are inconsistent with a formation by magma mixing.

The Rutog rocks have $\mathrm{T}_{\mathrm{DM}}$ ranging from 0.59 to $0.75 \mathrm{Ga}$, suggesting that they formed by melting of older crust. The relatively high $\varepsilon \mathrm{Nd}(\mathrm{t})$ values and low $\left({ }^{87} \mathrm{Sr} /{ }^{86} \mathrm{Sr}\right)_{\mathrm{i}}$ ratios suggest that their protolith was derived from a depleted mantle source. The Gangdese granitoids and Linzizong volcanic rocks in the same region have similar ${ }^{87} \mathrm{Sr}{ }^{86} \mathrm{Sr}$ ratios $(0.704$ $0.705)$ and $\varepsilon \mathrm{Nd}(\mathrm{t})$ values $(+2$ to +4$)$ (Harris et al. 1988), indicating that they shared a common source region.

The Rutog rocks have $\mathrm{Sr} / \mathrm{Y}$ ratios $(15.2-78)$ and $\mathrm{Y}$ contents (8.31-23.4) transitional between normal arc and adakitic compositions (Fig. 10a). Three samples that have relatively high $\mathrm{MgO}$ and $\mathrm{Y}$ (Fig. 10b) and plot in the field of normal arc rocks can be explained by accumulation of amphibole, because amphiboles have relatively high Y contents (Castillo, Janney \& Solidum, 1999). Partial melting of thickened, mafic continental crust $(>40 \mathrm{~km})$ under relatively high pressures normally produces adakites (Xu et al. 2002; Wang et al. 2005; Xiong, Adam \& Green, 2005; Zhao \& Zhou, 2008). Experiments have demonstrated that strongly fractionated adakite-like REE patterns, as well as low HREE contents, can only be generated from sources where garnet is stable under vapour-absent conditions at more than $1.2 \mathrm{Gpa}$ (Rapp, Watson \& Miller, 1991; Rapp \& Watson, 1995; Sen \& Dunn, 1994).

The temperatures of partial melting can be estimated by empirical equations for saturation temperatures of accessory mineral phases, such as monazite and zircon (Watson \& Harrison, 1983; Rapp, Ryerson \& Miller, 1987). Zr solubility is a function of the cation ratio $((\mathrm{Na}+\mathrm{K}+2 \mathrm{Ca}) /(\mathrm{Al} * \mathrm{Si}))$ and temperature in hydrous peraluminous or metaluminous melts (Fig. 11) (Watson \& Harrison, 1983). Using this formula, we calculate that the Rutog granodiorites were produced at about $800^{\circ} \mathrm{C}$.
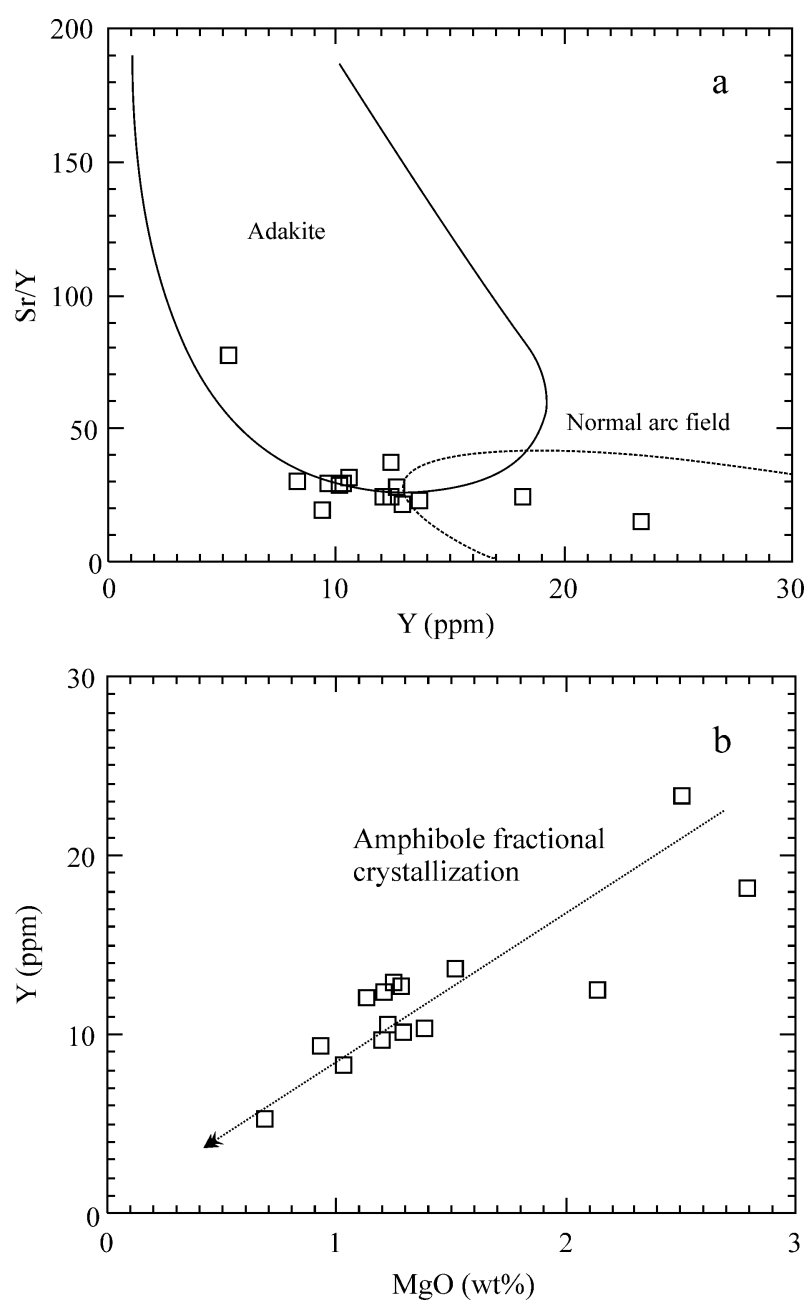

Figure 10. (a) $\mathrm{Sr} / \mathrm{Y}$ v. Y for the rocks from the Rutog pluton. Fields for adakite or high-Al TTG and normal arc andesite and dacite are from Drummond \& Defant (1990). (b) $\mathrm{MgO}$ v. Y for the rocks from the Rutog pluton showing the fractional crystallization of amphibole.

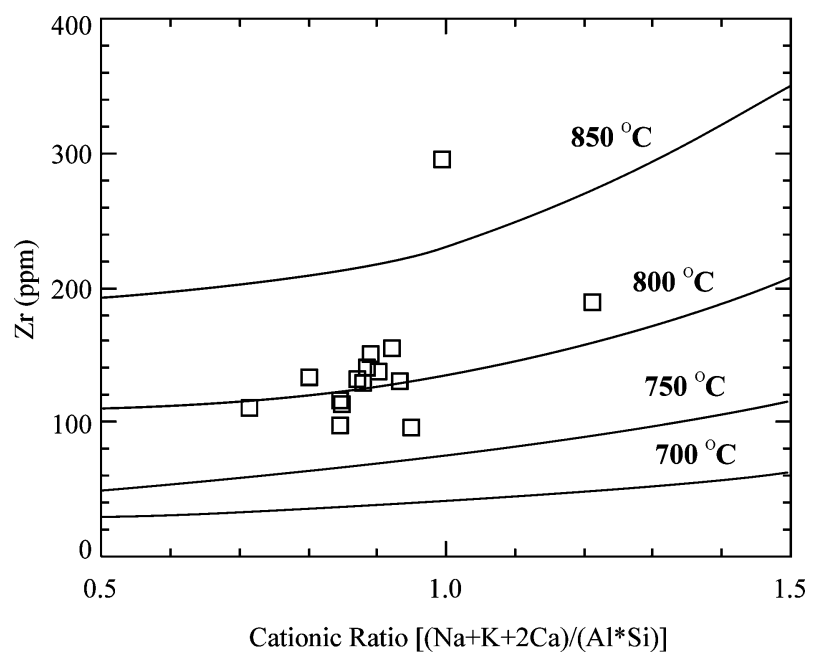

Figure 11. Plots of $\mathrm{Zr}$ concentration against the cation ratios of $(\mathrm{Na}+\mathrm{K}+2 \mathrm{Ca}) /(\mathrm{Al} * \mathrm{Si})$ (Watson \& Harrison, 1983).

Wu et al. $(2003 a, b)$ proposed a two-stage process to explain the highly fractionated I-type granites in NE China. We apply the same model to explain the petrogenesis of the Rutog pluton. In stage one, the 
parental magmas were generated by partial melting of the lower part of a thickened mafic crust and then underwent extensive differentiation at low pressures $(5-10 \mathrm{kbar})$ and temperatures $\left(800^{\circ} \mathrm{C}\right)$ at a later stage.

\section{6.d. Secular tectonic evolution of the Gangdese arc}

\section{6.d.1. Early Late Cretaceous crustal thickening in Tibet}

Recognition of the $c$. 80 Ma Rutog I-type granitoids has significant implications for the tectonic evolution of the Gangdese arc and the Tibetan Plateau as a whole.

Accretionary orogeny in southern Tibet may have occurred in Late Cretaceous times. Significant upper crustal shortening of the Lhasa Terrane during the Cretaceous resulted in thickening of the continental crust. In the Coqin area, Murphy et al. (1997) documented $>180 \mathrm{~km}$ of Cretaceous north-south shortening. The mid-Cretaceous Takena Formation near Lhasa experienced $\sim 40 \%$ shortening prior to deposition of the overlying Linzizong volcanic rocks (Y. Pan, unpub. Ph.D. thesis, State Univ. New York, 1993). Large parts of the Lhasa Terrane experienced crustal shortening during Cenozoic times (Yin et al. 1994).

Cretaceous shortening and magmatism in central Tibet are attributed to northward underthrusting of the Lhasa Terrane beneath the Qiangtang Terrane along the Bangong-Nujiang suture zone during low-angle subduction of Neo-Tethyan oceanic lithosphere (Kapp et al. 2005). Thus, there might have been substantial crustal thickening in Tibet prior to the India-Asia collision, consistent with the occurrence of the Rutog pluton. Tertiary shortening in central Tibet may record continuous underthrusting of the Lhasa Terrane along the Bangong-Nujiang suture, which may have both accommodated, and been driven by, insertion of the Indian subcontinent into a previously thickened Tibetan crust (Kapp et al. 2003).

The Lower Cretaceous strata deposited in a flexural foreland basin are thought to have resulted from the Lhasa-Qiangtang collision (Yin et al. 1994). The occurrence of widely exposed Albian-Aptian shallow marine strata is taken as evidence that the BangongNujiang suture zone was near sea level during midCretaceous times (Kapp et al. 2003).

Thus, we infer that during the early Late Cretaceous, Tibet was situated in an accretionary convergent margin where orogenic processes involving arc magmatism, crustal thickening and rapid tectonic uplift may have been operating actively. This interpretation further suggests that accretionary orogeny took place in the Late Cretaceous and that a high mountain range in the northern part of the Lhasa Terrane in the Late Cretaceous already existed in Tibet prior to the IndiaAsia collision.

\section{6.d.2. Post-orogenic origin and possible mechanism of melting}

Crustal melting is dependent on the thickness and temperature of the crust. Granitic melts are generated
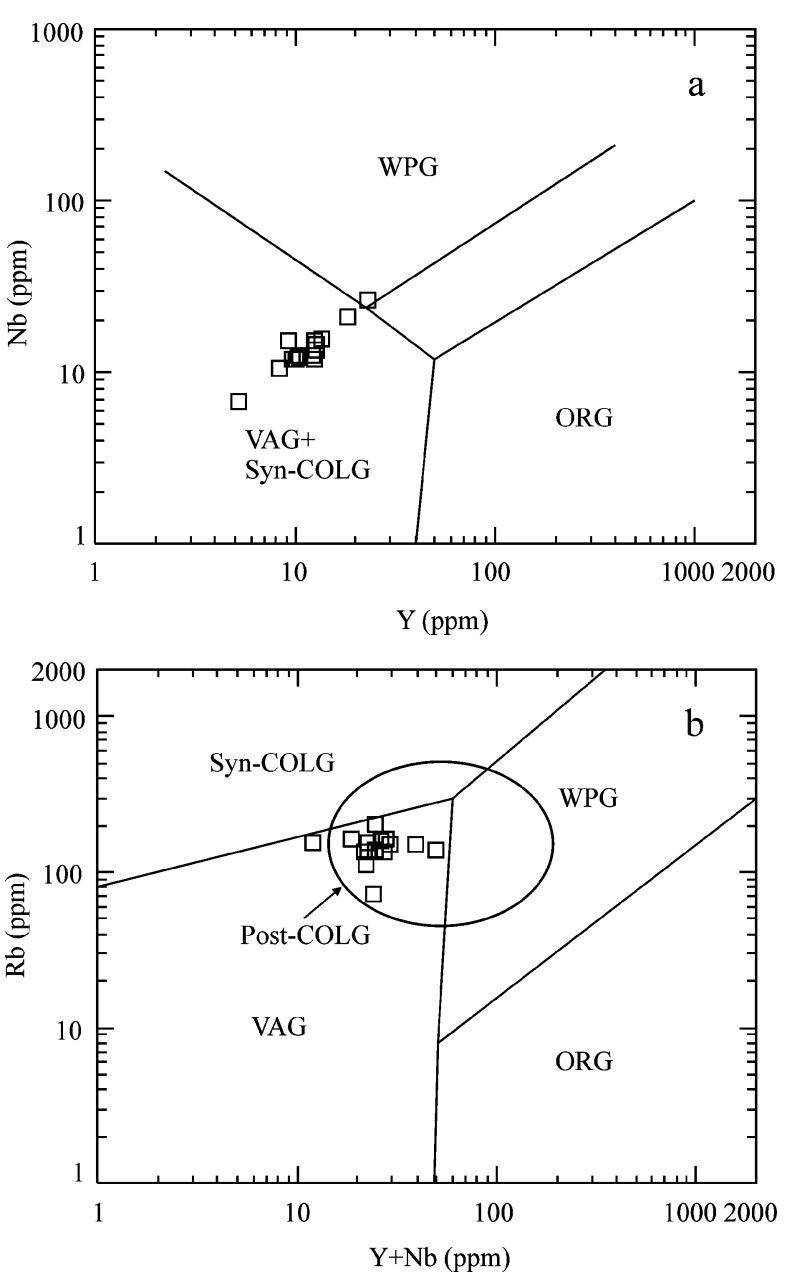

Figure 12. Plots of $\mathrm{Y} v \mathrm{v} . \mathrm{Nb}(\mathrm{a})$ and $\mathrm{Y}+\mathrm{Nb}$ v. $\mathrm{Rb}$ (b) for rocks from the Rutog pluton. Reference fields are from Pearce, Harris $\&$ Tindle (1984). Syn-COLG - Syn-collisional Granite; WPG Within Plate Granite; ORG - Orogenic Granites; VAG - Volcanic Arc Granite.

where thickened crust is affected by (a) major crustal shears or thrusts (e.g., Barbarin, 1996), (b) in situ radiogenic heating from the over-thickened crust and (c) conductive heating from underplated magma in a post-collisional setting (e.g. Wang et al. 2007).

The negative $\mathrm{Nb}$ and $\mathrm{Ti}$ anomalies of the Rutog pluton are similar to those of syn-collisional granites in continental margins, indicating that the Rutog granitoids formed in a collisional environment (Pearce et al. 1984). On the Y v. Nb diagram, all of the Rutog samples plot in the field of volcanic arc granites (Fig. 12a), whereas on the $\mathrm{Y}+\mathrm{Nb} \mathrm{v}$. $\mathrm{Rb}$ diagram they fall in the field of post-orogenic granitic rocks (Fig. 12b). In addition, all of the Rutog samples plot in the late orogenic field on the $R_{1}-R_{2}$ diagram (Fig. 13), suggesting that these rocks formed in a post-orogenic setting during early Cretaceous times.

We therefore propose that the Rutog pluton formed by crustal melting during continent-continent collision following closure of the Bangong-Nujiang Tethyan ocean. The emplacement of ophiolites along the Bangong-Nujiang suture zone may have occurred at $173 \mathrm{Ma}$ (Zhou et al. 1997), and collision of the 


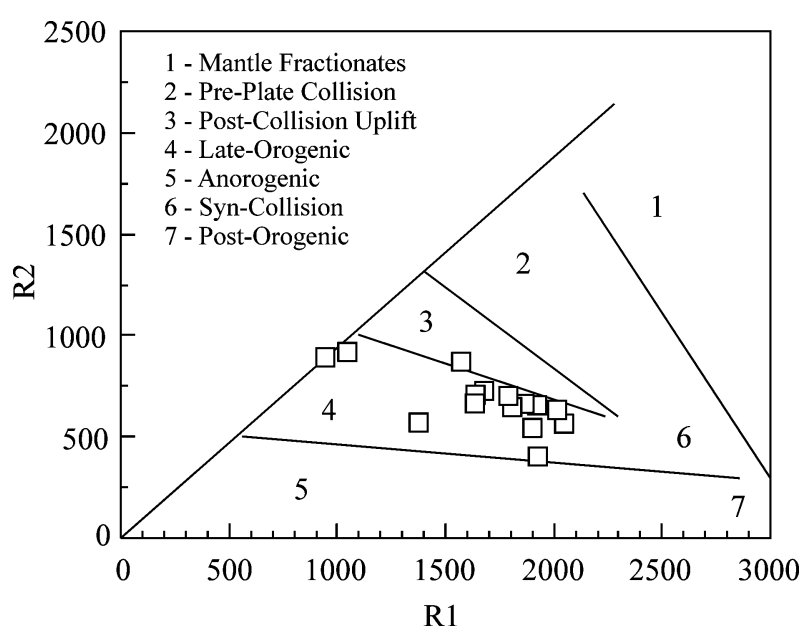

Figure 13. $\mathrm{R}_{1}-\mathrm{R}_{2}$ multi-cationic diagram of rocks from the Rutog pluton (after De la Roche et al. 1980). $R_{1}$ and $R_{2}$ are parameters calculated from chemical analyses, $R_{1}=4 \mathrm{Si}-$ $11(\mathrm{Na}+\mathrm{K})-2(\mathrm{Fe}+\mathrm{Ti})$ and $R_{2}=6 \mathrm{Ca}+2 \mathrm{Mg}+\mathrm{Al}$.

Qiangtang and Lhasa terranes occurred at least in the late early Cretaceous (about $100 \mathrm{Ma}$ ) (Pan, Wang \& Li, 2002), $20 \mathrm{Ma}$ earlier than the formation of the $80 \mathrm{Ma}$ Rutog pluton.

Following closure of the ocean and crustal thickening, some areas of the orogen were invaded by mafic magmas, which promoted dehydration melting of the crustal rocks, generating large volumes of postorogenic K-rich calc-alkaline granitic rocks including the Rutog pluton. The $\mathrm{Sr}-\mathrm{Nd}$ isotopic compositions of these rocks indicate that the original magmas were mostly derived from juvenile Neoproterozoic arc material.

Partial melting of this crust was probably initiated by underplating of mafic magma above a flat subduction zone at c. $80 \mathrm{Ma}$. The wide distribution of Cretaceous arc magmatism in southern Tibet has led some workers to suggest that flat subduction occurred in the region before the India-Asia collision (e.g. Coulon et al. 1986).

\section{Conclusions}

The Rutog granitic pluton is a composite body with an age of $80 \mathrm{Ma}$. The Rutog rocks are geochemically I-type granitoids, and were formed by partial melting of a lower part of a thickened continental crust and emplaced at a shallow depth above a flat subduction zone from the south.

Acknowledgements. This work was supported by the CAS Hundred Talents Project (to ZKJ). The authors thank Ms Tao Hua for her assistance with the zircon SHRIMP U-Pb isotope analyses and $\mathrm{Xu}$ Yong-Hang for his help with the XRF and ICP-MS analyses. Zhang Yuxiu and Zhong Lifeng assisted with the field work. We thank Prof. Nick T. Arndt, Prof. Paul T. Robinson, and Dr Christina Y. Wang for their comments that helped to improve an early version of this paper. We also thank Dr Mark Allen and Mrs Jane Holland for their editorial work.

\section{References}

Aitchison, J. C., Badengzhu, D. A. M., LiU, J., Luo, H., Malpas, J., McDermid, I., Wu, H., ZiabreV, S. \& ZHOU, M. F. 2000. Remnants of a Cretaceous intraoceanic subduction system within the YarlungZangbo suture (southern Tibet). Earth and Planetary Science Letters 183, 231-44.

ALLÈGRE, C. J. \& 34 others. 1984. Structure and evolution of the Himalayan-Tibet orogenic belt. Nature 307, 17-22.

BARBARIN, B. 1996. Genesis of the two main types of peraluminous granitoids. Geology 24, 295-8.

Castillo, P. R., Janney, P. E. \& Solidum, R. U. 1999. Petrology and geochemistry of Camiguin Island, southern Philippines: insights to the source of adakites and other lavas in a complex arc setting. Contributions to Mineralogy and Petrology 134, 33-51.

CHANG, C. F. \& ZHENG, S. L. 1973. Tectonic features of the Mount Jolmo Lungma region in southern Tibet, China. Scientia Geological Sinica 1, 11-2 (in Chinese with English abstract).

CHAPPELL, B. W. 1996. Magma mixing and the production of compositional variation within granite suites: evidence from the granites of Southeastern Australia. Journal of Petrology 37, 449-70.

Chappell, B. W. \& White, A. J. R. 1974. Two contrasting granite types. Pacific Geology 8, 173-4.

Chappell, B. W. \& White, A. J. R. 1992. I- and S-type granites in the Lachlan Fold Belt. Transactions of the Royal Society of Edinburgh 83, 1-26.

Chappell, B. W. \& White, A. J. R. 2001. Two contrasting granite types: 25 years later. Australian Journal of Earth Sciences 48, 489-99.

Coulon, C., Maluski, H., Bollinger, C. \& Wang, S. 1986. Mesozoic and Cenozoic volcanic rocks from central and southern Tibet: ${ }^{39} \mathrm{Ar} /{ }^{40} \mathrm{Ar}$ dating, petrological characteristics and geodynamical significance. Earth and Planetary Science Letters 79, 281-302.

De la Roche, H., Leterrier, J., Grand Claude, P. \& MARCHAL, M. 1980. A classification of volcanic and plutonic rocks using R1-R2 diagrams and major element analyses - its relationship with current nomenclature. Chemical Geology 29, 183-210.

Drummond, M. S. \& Defant, M. J. 1990. A model for trondhjemite-tonalite-dacite genesis and crustal growth via slab melting: Archean to modern comparisons. Journal of Geophysical Research 95, 21503-21.

Goto, A. \& TATsUMI, Y. 1996. Quantitative analyses of rock samples by X-ray fluorescence spectrometer (II). Rigaku-Denki Journal 13, 20-39 (in Japanese).

Harris, N. B. W., XU, R. H., Lewis, C. L., HaWKesworth, C. \& ZHANG, Y. Q. 1988. Isotope geochemistry of the 1985 Tibet Geotraverse: Lhasa to Golmud. Philosophical Transactions of the Royal Society, London A327, 263-85.

Hodges, K. V. 2000. Tectonics of the Himalaya and southern Tibet from two perspectives. GSA Bulletin $\mathbf{1 1 2}$ 324-50.

Johannes, W. \& Holtz, F. 1996. Petrogenesis and Experimental Petrology of Granitic Rocks. Berlin: Springer, $335 \mathrm{pp}$.

KapP, J. L. D., Harrison, T. M., KapP, P., Grove, M., LOVERA, O. M. \& DING, L. 2005. The Nyainqentanglha Shan: A window into the tectonic, thermal, and geochemical evolution of the Lhasa block, southern Tibet. Journal of Geophysical Research 110, B08413.

KAPP, P., MurPhy, M. A., YIN, A., HARrison, T. M., Ding, L. \& GuO, J. 2003. Mesozoic and Cenozoic 
tectonic evolution of the Shiquanhe area of western Tibet. Tectonics 22, 1029.

Kapp, P., Yin, A., Harrison, T. M. \& Ding, L. 2005. Cretaceous-Tertiary shortening, basin development, and volcanism in central Tibet. GSA Bulletin 117, 86578.

LI, X. H., LI, Z. X., LI, W. X., LIU, Y., YUAN, C., WEI, G. J. \& QI, C. S. 2007. U-Pb zircon, geochemical and $\mathrm{Sr}-\mathrm{Nd}-$ $\mathrm{Hf}$ isotopic constraints on age and origin of Jurassic Iand A-type granites from central Guangdong, SE China: A major igneous event in response to foundering of a subducted flat-slab? Lithos 96, 186-204.

Litvinovsky, B. A., JAHN, B. M., ZANVILEVICH, A. N. \& SHADAEV, M. G. 2002. Crystal fractionation in the petrogenesis of an alkali monzodiorite-syenite series: the Oshurkovo plutonic sheeted complex, Transbaikalia, Russia. Lithos 64, 97-130.

LU, S. W., ZhANG, L. \& REN, J. D. 2004. Zonality of the Gangdese magmatic arc on the Qinghai-Tibet plateau and geological significance. Geological Bulletin of China 23, 1023-32 (in Chinese with English abstract).

LUDWIG, K. R. 2001. Squid 1.02: A user's manual. Berkeley Geochronology Center, Special Publication no. 2, 19 pp.

Matte, P., TAPPONNIER, P., ARnaud, N., BourJot, L., Avouac, J. P., VidaAl, P., LiU, Q., Pan, Y. \& WanG, Y. 1996. Tectonics of western Tibet between the Tarim and Indus. Earth and Planetary Science Letters 142, $311-30$.

Mo, X. X., ZhaO, Z. D., DenG, J. F., DONG, G. C., Zhou, S., GuO, T. Y., ZHANG, S. Q. \& WANG, L. L. 2003. Response of volcanism to the India-Asia collision. Earth Science Frontiers 10, 135-48.

MolnAR, P. \& TAPPONNIER, P. 1975. Cenozoic tectonics of Asia; effects of a continental collision. Science 189, 419-26.

Murphy, M. A., Yin, A., HARrison, T. M., DÜRR, S. B., Chen, Z., RYERson, F. J., KidD, W. S. F., WANG, X. \& ZHOU, X. 1997. Did the Indo-Asian collision alone create the Tibetan plateau? Geology 25, 719-22.

Pan, G. T., Mo, X. X., HoU, Z. Q., ZhU, D. C., WanG, L. Q., LI, G. M., ZHAO, Z. D., GENG, Q. R. \& LIAO, Z. L. 2006. Spatial-temporal framework of the Gangdes Orogenic Belt and its evolution. Acta Petrologica Sinica 22, 521-33.

PAN, G. T., WANG, L. Q. \& LI, X. Z. 2002. The tectonic framework and spatial allocation of the archipelagic arcbasin systems on the Qinghai-Tibet Plateau. Sedimentary Geology and Tethyan Geology 21, 1-26 (in Chinese with English abstract).

Pearce, J. A., Harris, N. B. W. \& Tindle, A. G. 1984. Trace-element discrimination diagrams for the tectonic interpretation of granitic rocks. Journal of Petrology $\mathbf{2 5}$, 956-83.

PIERCE, J. A. \& MEI, H. 1988. Volcanic rocks of the 1985 Tibet Geotraverse Lhasa to Golmud. Philosophical Transactions of the Royal Society, London A327, 20313.

PITCHER, W. S. 1982. Granite type and tectonic environment. In Mountain Building Processes (ed. K. J. Hsu), pp. 19 40. London: Academic Press.

PITCHER, W. S. 1993. The Nature and Origin of Granite. London: Blackie Academic and Professional, $321 \mathrm{pp}$.

QI, L., HU, J. \& GREGOIRE, D. C. 2000. Determination of trace elements in granites by inductively coupled plasmamass spectrometry. Talanta 51, 507-13.

RAPP, R. P. \& WATSON, E. B. 1995. Dehydration melting of metabasalt at 8-32 kbar: implications for continental growth and crust-mantle recycling. Journal of Petrology 36, 891-931.

Rapp, R. P., Ryerson, F. J. \& Miller, C. F. 1987. Experimental evidence bearing on the stability of monazite during crustal anatexis. Geophysical Research Letters 14, 307-10.

Rapp, R. P., Watson, E. B. \& Miller, C. F. 1991. Partial melting of amphibolite/ecolgite and the origin of Archaean trondhjemites and tonalites. Precambrian Presearch 51, 1-25.

Ratschbacher, L., Frisch, W., Lui, G. \& Chen, C. 1994. Distributed deformation in southern and western Tibet during and after the India-Asia collision. Journal of Geophysical Research (Part B) 99, 19817945.

SEN, C. \& DunN, T. 1994. Experimental modal metasomatism of spinel lherzolite and the production of amphibolebearing peridotite. Contributions to Mineralogy and Petrology 119, 422-32.

Shannon, J. R., Walker, B. M., Carten, R. B. \& GERAGHTY, E. P. 1982. Unidirectional solidification textures and their significance in determining relative ages of intrusions at the Henderson Mine, Colorado. Geology 10, 293-7.

SteigeR, R. H. \& JÄGER, E. 1977. Subcommission on geochronology: convention on the use of decay constants in geo- and cosmochronology. Earth and Planetary Science Letters 36, 359-62.

Sun, S. S. \& McDonough, W. F. 1989. Chemical and isotopic systematics of oceanic basalts: implications for mantle composition and processes. In Magmatism in the ocean basins (eds A. D. Saunders \& M. J. Norry), pp. 313-45. Geological Society of London, Special Publication no. 42.

Sun, W.-H. \& ZHOU, M.-F. 2008. The 860-Ma, Cordillerantype Guandaoshan dioritic pluton in the Yangtze Block, SW China: implications for the origin of Neoproterozoic magmatism. Journal of Geology 116, doi: $10.1086 / 587881$, in press.

TANAKA, T. \& 18 others. 2004. JNdi-1: a neodymium isotopic reference in consistency with La Jolla neodymium. Chemical Geology 168, 279-81.

TBGMR (TIBETAN BUREAU OF GEOLOGY AND MineRAL RESOURCES,). 1993. Regional geology of Xizang (Tibet) Autonomous Region. Beijing: Geological Publishing House. Geological Memoirs 1(31), 699 pp. (in Chinese with English abstract).

WANG, Q., MCDERmott, F., XU, J. F., Bellon, H. \& ZHU, Y. T. 2005. Cenozoic K-rich adakitic volcanic rocks in the Hohxil area, northern Tibet: lower-crustal melting in an intracontinental setting. Geology 33, 465-8.

WANG, Y. J., FAN, W. M., SUn, M., LiANG, X. Q., ZHANG, Y. H. \& PENG, T. P. 2007. Geochronological, geochemical and geothermal constraints on petrogenesis of the Indosinian peraluminous granites in the South China Block: A case study in the Hunan Province. Lithos 96, 475-502.

WATSON, E. B. \& HARRISON, T. M. 1983. Zircon saturation revisited: temperature and composition effects in a variety of crustal magma types. Earth and Planetary Science Letters 64, 295-304.

Whalen, J. B., Currie, K. L. \& Chappell, B. W. 1987. A-type granites: geochemical characteristics, discrimination and petrogenesis. Contributions to Mineralogy and Petrology 95, 407-19.

Wu, F. Y., Jahn, B. M., Wilde, S. A., Lo, C. H., YuI, T. F., LIN, Q., GE, W. C. \& Sun, D. Y. 2003a. Highly fractionated I-type granites in NE China (II): isotopic 
geochemistry and implications for crustal growth in the Phanerozoic. Lithos 67, 191-204.

Wu, F. Y., JAHN, B. M., Wilde, S. A., Lo, C. H., YuI, T. F., LiN, Q., GE, W. C., Sun, D. Y. $2003 b$. Highly fractionated I-type granites in NE China (I): geochronology and petrogenesis. Lithos 66, 24173.

Xiong, X. L., AdAm, J. \& GreEn, T. H. 2005. Rutile stability and rutile/melt HFSE partitioning during partial melting of hydrous basalt: Implications for TTG genesis. Chemical Geology 218, 33959.

Xu, J. F., Shinjio, R., Defant, M. J., Wang, Q. \& Rapp, R. P. 2002. Origin of Mesozoic adakitic intrusive rocks in the Ningzhen area of east China: partial melting of delaminated lower continental crust? Geology 32, 111114.

YAnG, J. H., Wu, F. Y., WiLde, S. A., XIE, L. W., YAnG, Y. H. \& LIU, X.-M. 2007. Tracing magma mixing in granite genesis: in situ $\mathrm{U}-\mathrm{Pb}$ dating and $\mathrm{Hf}$-isotope analysis of zircons. Contributions to Mineralogy and Petrology 153, 177-90.
YIN, A. \& HARRISON, T. M. 2000. Geologic evolution of the Himalayan-Tibetan orogen. Annual Review of Earth and Planetary Sciences 28, 211-80.

Yin, A., HARRISON, T. M., RYERSON, F. J., CHEN, W., KIDD, W. S. F. \& Copeland, P. 1994. Tertiary structural evolution of the Gangdese thrust system, southeastern Tibet. Journal of Geophysical Research (Part B) 99, 18175-201.

ZhaO, T. P., Zhai, M. G., XiA, B., Li, H. M., Zhang, Y. X. \& WAN, Y. S. 2004. Study on the zircon SHRIMP ages of the Xiong'er Group volcanic rocks: constraints on the starting time of covering strata in the North China Craton. Chinese Science Bulletin 9, 2495-502.

ZHAO, J. H. \& ZHOU, M. F. 2008. Neoproterozoic adakitic plutons in the northern margin of the Yangtze Block, China: Partial melting of a thickened lower crust and implications for secular crustal evolution. Lithos doi:10.1016/j.lithos.2007.12.009, in press.

Zhou, M. F., Malpas, J., Robinson, P. T. \& Reynolds, P. H. 1997. The dynamothermal aureole of the Donqiao ophiolite (northern Tibet). Canadian Journal of Earth Sciences 34, 59-65. 